Original Research Paper

\title{
Dynamic Models for Rigid Memory Mechanisms
}

\author{
Relly Victoria Virgil Petrescu \\ ARoTMM-IFToMM, Bucharest Polytechnic University, Bucharest, (CE), Romania
}

\author{
Article history \\ Received: 18-04-2019 \\ Revised: 23-04-2019 \\ Accepted: 04-05-2019 \\ Email: rvvpetrescu@gmail.com
}

\begin{abstract}
The paper presents a dynamic model that works with variable internal damping, applicable directly to rigid memory mechanisms. If the problem of elasticity is generally solved, the problem of system damping is not clear and well-established. It is usually considered a constant "c" value for the internal damping of the system and sometimes the same value $\mathrm{c}$ and for the damping of the elastic spring supporting the valve. However, the approximation is much forced, as the elastic spring damping is variable and for the conventional cylindrical spring with constant elasticity parameter (k) with linear displacement with force, the damping is small and can be considered zero. It should be specified that damping does not necessarily mean stopping (or opposition) movement, but damping means energy consumption to brake the motion (rubber elastic elements have considerable damping, as are hydraulic dampers). Metal helical springs generally have a low (negligible) damping. The braking effect of these springs increases with the elastic constant (the k-stiffness of the spring) and the force of the spring $\left(\mathrm{P}_{0}\right.$ or $\left.\mathrm{F}_{0}\right)$ of the spring (in other words with the arc static arrow, $\left.x_{0}=P_{0} / k\right)$. Energy is constantly changing but does not dissipate (for this reason, the yield of these springs is generally higher). The paper presents a dynamic model with a degree of freedom, considering internal damping of the system (c), damping for which it is considered a special function. More precisely, the cushioning coefficient of the system (c) is defined as a variable parameter depending on the reduced mass of the mechanism ( $\mathrm{m}^{*}$ or $\mathrm{J}$ reduced) and the time, i.e., $\mathrm{c}$ depends on the derivative of $m$ reduced in time. The equation of the differential movement of the mechanism is written as the movement of the valve as a dynamic response.
\end{abstract}

Keywords: Robots, Mechatronic Systems, Structure, Dynamics, Dynamics Systems, Machines, Dynamic Models, Rigid Memory Mechanisms

\section{Introduction}

Since today's robotics have grown at a rapid pace, it is necessary to better understand the phenomena that occur in robotic and mechatronic systems. Robots have not only penetrated to create microchips in electronics but also in medicine, where it helps to perform difficult operations, especially where precision is needed and the size is small and any human error could be fatal to the patient. Robots assist the doctor in heart, brain, kidney operations, not to mention bone implants and repair of damaged bones, cartilage and muscles. In this area, new materials adapted to the requirements of the human body also play an important role. Robots can usually do things much more accurate than a man. This provides the first motivation for using CAD/CAM systems. Robots can be used successfully if the patient has been radiated (e.g., with X-radiation), thus not endangering the health of the medical team. Since ancient times, the imagination of mankind has been concerned with the idea of making cars equipped with artificial intelligence to execute operations similar to those performed by man. Technicians have been used for many years in various fields other than medical, such as the automotive industry, the underwater environment, the alien space, or the areas at risk of nuclear radiation.

A robot is a mechanic or virtually artificial engineer. The robot is a system composed of several elements: Mechanical, sensors and actuators as well as a steering mechanism. The mechanics determine the appearance of the robot and the possible movements during operation. Sensors and actuators are used when interacting with the system environment. The targeting mechanism ensures that the robot accomplishes its goal 
successfully, for example by evaluating sensor information. This mechanism regulates the engines and plans the movements to be made. Robots with human form are called androids.

The basics of today's robots are far ahead. The first models of cars can be called automated (coming from the automated Greek, moving alone). They could do only one goal, being constrained by construction.

The Greek mathematician, Archytas, has, according to some accounts, built one of these automated primes: A propelled steamed pigeon that could fly alone. This wooden cavern was filled with air under pressure. It had a valve that allowed opening and closing by a counterweight. There have been many models over the centuries. Some made work easier and others served to people's amusement.

With the discovery of the 14th-century mechanical clock, new and complex possibilities have opened up. Not long afterward, the first machines appeared, which resembled the robots today. It was possible, however, that the movements followed one another without the need for manual intervention in that system.

The development of electro-technics in the twentieth century brought with it a development of robotics. Among the first mobile robots are the Elmer and Elsie system built by William Gray Walter in 1948. These tricycles could point to a light source and recognize collisions in the surroundings.

The year 1956 is considered as the birthday of the industrial robot. George Devol has applied this year in the US for a patent for "scheduled article transfer". A few years later he built together with Joseph Engelberger UNIMATE. This robot of approx. two tons was first introduced into the installation of TV iconoscopes and then found its way into the automotive industry. The programs for this robot were saved in the form of directional commands for motors on a magnetic cylinder. Since then, industrial robots as UNIMATE have been introduced in many production areas and are continually being developed to meet the complex demands that are required.

Intelligent robots possess elements of artificial intelligence. They can define their own tasks to solve particular problems by considering information about the environment (organized in the environment model) and can modify their actions according to the information provided by the perception system. Intelligent robots can be completely autonomous, their intelligence depending on the purpose for which they are built. The intelligent robot can be defined as a system able to perform tasks that require certain human qualities: Adaptation, learning, environmental imaging, prediction and planning, etc.

The assembly of the command system, the drive system and the perception system is the driving system.
The mechanical system is the driven system. The robot's structure can, therefore, be divided into the mechanical structure and the electronic structure. The robot interacts with the environment by means of the mechanical structure, ensuring the displacement, positioning and orientation of the final effector.

Workspace is the environment in which the robot evolves to accomplish the planned task, populated with physical, fixed or mobile objects.

The useful workspace is described by the movements of all kinematic couplings within the limits defined by the drive motors. Throughout the movement of the robot elements, its effector must be contained within the useful workspace. In the case of a mobile robot, defining and shaping the workspace requires a global approach to the entire robot action zone, so also to the obstacles.

The development and diversification of road vehicles and general vehicles, especially of cars, together with thermal engines, especially internal combustion engines (being more compact, robust, more independent, more reliable, stronger, more dynamic etc.)., has also forced the development of devices, mechanisms and component assemblies at an alert pace. The most studied are power and transmission trains.

The four-stroke internal combustion engine (fourstroke, Otto or Diesel) comprises in most cases (with the exception of rotary motors) and one or more camshafts, valves, valves and so on.

The classical distribution mechanisms are robust, reliable, dynamic, fast-response and although they functioned with very low mechanical efficiency, taking much of the engine power and effectively causing additional pollution and increased fuel consumption, they could not be abandoned until the present. Another problem was the low speed from which these mechanisms begin to produce vibrations and very high noises.

Regarding the situation realistically, the mechanisms of cam casting and sticking are those that could have produced more industrial, economic, social revolutions in the development of mankind. They have contributed substantially to the development of internal combustion engines and their spreading to the detriment of external combustion (Steam or Stirling) combustion engines.

The problem of very low yields, high emissions and very high power and fuel consumption has been greatly improved and regulated over the past 20-30 years by developing and introducing modern distribution mechanisms that, besides higher yields immediately deliver a high fuel economy also performs optimal noisefree, vibration-free, no-smoky operation, as the maximum possible engine speed has increased from 6000 to 30000 [rpm].

The paper tries to provide additional support to the development of distribution mechanisms so that their performance and the engines they will be able to further enhance. 
Particular performance is the further increase in the mechanical efficiency of distribution systems, up to unprecedented quotas so far, which will bring a major fuel economy.

The current oil and energy reserves of mankind are limited. Until the implementation of new energy sources (to take real control over fossil fuels), a real alternative source of energy and fuel is even "the reduction in fuel consumption of a motor vehicle", whether we burn oil, gas and petroleum derivatives, whether we will implement biofuels first and later hydrogen (extracted from water).

The drop in fuel consumption for a given vehicle type over a hundred kilometers traveled has been consistently since 1980 and has continued to continue in the future.

Even if hybrids and electric motor cars are to be multiplied, let us not forget that they have to be charged with electricity, which is generally obtained by burning fossil fuels, especially oil and gas, in a current planetary proportion of about $60 \%$. Can burn oil in large heat plants to warm up, have domestic hot water and electricity to consume and some of that energy is extra and we add it to electric cars (electric vehicles), but the global energy problem is not resolved, the crisis even deepens. This was the case when was electrified the railroad for trains, when it were generalized trams, trolleybuses and subways, consuming more electric power produced mainly from oil; oil consumption has grown a lot, its price has had a huge leap and now one looks at how the reserves disappear quickly.

Generally, generalizing electric cars (though it is not really ready for this), one will give a new blow to oil and gas reserves.

Fortunately, biofuels, biomass and nuclear power have developed very much lately (currently based on the nuclear fission reaction). These together with the hydroelectric power plants have managed to produce about $40 \%$ of the total energy consumed globally. Only about $2-3 \%$ of global energy resources are produced by various other alternative methods (despite the efforts made so far).

This should not disarm us and abandon the implementation of solar, wind, etc.

However, as a first necessity to further reduce the share of global energy from oil and gas, the first vigorous measures that will need to be pursued will be to increase biomass and biofuels production along with the widening of the number of nuclear power plants (despite some undesirable events, which only show that nuclear fission power plants must be built with a high degree of safety and in no way eliminated from now on and they are still the one that has been so far "a bad evil ").

Alternative sources will take them on an unprecedented scale, but it expects the energy they provide to be more consistent in global percentages so that can rely on them in a real way (otherwise, one risks that all these alternative energies remain a sort of "fairy tale").

Hydrogen fuel energy "when it starts when it stops" so there is no real time now to save energy through them, so they can no longer be priority, but the trucks and buses could even be implemented now that the storage problems have been partially solved. The bigger problem with hydrogen is no longer the safe storage, but the high amount of energy needed to extract it and especially for its bottling. The huge amount of electricity consumed for bottling hydrogen will have to be obtained entirely through alternative energy sources, otherwise hydrogen programs will not be profitable for humanity at least for the time being. The authors thinking the immediate use of hydrogen extracted from the water with alternative energies would be more appropriate for seagoing vessels.

Maybe just to say that due to his energy crisis (and not just energy, from 1970 until today), the production of cars has increased at an alert pace (but naturally) instead of falling and they have and were marketed and used. The world's energy crisis (in the 1970s) began to rise from around 200 million vehicles worldwide, to about 350 million in 1980 (when the world's energy and global fuel crisis was declared), about 500 million vehicles worldwide and in 1997 the number of worldregistered vehicles exceeded 600 million (Rulkov et al., 2016; Agarwala, 2016; Babayemi, 2016; Gusti and Semin, 2016; Mohamed et al., 2016; Wessels and Raad, 2016; Maraveas et al., 2015; Khalil, 2015; RhodeBarbarigos et al., 2015; Takeuchi et al., 2015; Li et al., 2015; Vernardos and Gantes, 2015; Bourahla and Blakeborough, 2015; Stavridou et al., 2015; Ong et al., 2015; Dixit and Pal, 2015; Rajput et al., 2016; Rea and Ottaviano, 2016; Zurfi and Zhang, 2016a; 2016b; Zheng and Li, 2016; Buonomano et al., 2016a; 2016b; Faizal et al., 2016; Cataldo, 2006; Ascione et al., 2016; Elmeddahi et al., 2016; Calise et al., 2016; Morse et al., 2016; Abouobaida, 2016; Rohit and Dixit, 2016; Kazakov et al., 2016; Alwetaishi, 2016; Riccio et al., 2016a; 2016b; Iqbal, 2016; Hasan and El-Naas, 2016; Al-Hasan and Al-Ghamdi, 2016; Jiang et al., 2016; Sepúlveda, 2016; Martins et al., 2016; Pisello et al., 2016; Jarahi, 2016; Mondal et al., 2016; Mansour, 2016; Al Qadi et al., 2016b; Campo et al., 2016; Samantaray et al., 2016; Malomar et al., 2016; Rich and Badar, 2016; Hirun, 2016; Bucinell, 2016; Nabilou, 2016b; Barone et al., 2016; Chisari and Bedon, 2016; Bedon and Louter, 2016; Santos and Bedon, 2016; Minghini et al., 2016; Bedon, 2016; Jafari et al., 2016; Chiozzi et al., 2016; Orlando and Benvenuti, 2016; Wang and Yagi, 2016; Obaiys et al., 2016; Ahmed et al., 2016; Jauhari et al., 2016; Syahrullah and Sinaga, 2016; Shanmugam, 2016; Jaber and Bicker, 2016; Wang et al., 2016; Moubarek and Gharsallah, 2016; Amani, 2016; 
Shruti, 2016; Pérez-de León et al., 2016; Mohseni and Tsavdaridis, 2016; Abu-Lebdeh et al., 2016; Serebrennikov et al., 2016; Budak et al., 2016; Augustine et al., 2016; Jarahi and Seifilaleh, 2016; Nabilou, 2016a; You et al., 2016; Al Qadi et al., 2016a; Rama et al., 2016; Sallami et al., 2016; Huang et al., 2016; Ali et al., 2016; Kamble and Kumar, 2016; Saikia and Karak, 2016; Zeferino et al., 2016; Pravettoni et al., 2016; Bedon and Amadio, 2016; Chen and $\mathrm{Xu}, 2016$; Mavukkandy et al., 2016; Gruener, 2006; Yeargin et al., 2016; Madani and Dababneh, 2016; Alhasanat et al., 2016; Elliott et al., 2016; Suarez et al., 2016; Kuli et al., 2016; Waters et al., 2016; Montgomery et al., 2016; Lamarre et al., 2016; Daud et al., 2008; Taher et al., 2008; Zulkifli et al., 2008; Pourmahmoud, 2008; Pannirselvam et al., 2008; Ng et al., 2008; El-Tous, 2008; Akhesmeh et al., 2008; Nachiengtai et al., 2008; Moezi et al., 2008; Boucetta, 2008; Darabi et al., 2008; Semin and Bakar, 2008; AlAbbas, 2009; Abdullah et al., 2009; Abu-Ein, 2009; Opafunso et al., 2009; Semin et al., 2009a; 2009b; 2009c; Zulkifli et al., 2009; Marzuki et al., 2015; Bier and Mostafavi, 2015; Momta et al., 2015; Farokhi and Gordini, 2015; Khalifa et al., 2015; Yang and Lin, 2015; Chang et al., 2015; Demetriou et al., 2015; Rajupillai et al., 2015; Sylvester et al., 2015; Ab-Rahman et al., 2009; Abdullah and Halim, 2009; Zotos and Costopoulos, 2009; Feraga et al., 2009; Bakar et al., 2009; Cardu et al., 2009; Bolonkin, 2009a; 2009b; Nandhakumar et al., 2009; Odeh et al., 2009; Lubis et al., 2009; Fathallah and Bakar, 2009; Marghany and Hashim, 2009; Kwon et al., 2010; Aly and Abuelnasr, 2010; Farahani et al., 2010; Ahmed et al., 2010; Kunanoppadon, 2010; Helmy and El-Taweel, 2010; Qutbodin, 2010; Pattanasethanon, 2010; Fen et al., 2011; Thongwan et al., 2011; Theansuwan and Triratanasirichai, 2011; Al Smadi, 2011; Tourab et al., 2011; Raptis et al., 2011; Momani et al., 2011; Ismail et al., 2011; Anizan et al., 2011; Tsolakis and Raptis, 2011; Abdullah et al., 2011; Kechiche et al., 2011; Ho et al., 2011; Rajbhandari et al., 2011; Aleksic and Lovric, 2011; Kaewnai and Wongwises, 2011; Idarwazeh, 2011; Ebrahim et al., 2012; Abdelkrim et al., 2012; Mohan et al., 2012; Abam et al., 2012; Hassan et al., 2012; Jalil and Sampe, 2013; Jaoude and El-Tawil, 2013; Ali and Shumaker, 2013; Zhao, 2013; El-Labban et al., 2013; Djalel et al., 2013; Nahas and Kozaitis, 2013; Petrescu and Petrescu, 2014a; 2014b; 2014c; 2014d; 2014e; 2014f; 2014g; 2014h; 2014i; 2015a; 2015b; 2015c; 2015d; 2015e; 2016a; 2016b; 2016c; 2016d; Fu et al., 2015; Al-Nasra et al., 2015; Amer et al., 2015; Sylvester et al., 2015b; Kumar et al., 2015; Gupta et al., 2015; Stavridou et al., 2015b; Casadei, 2015; Ge and Xu, 2015; Moretti, 2015; Wang et al., 2015; Antonescu and Petrescu, 1985; 1989; Antonescu et al., 1985a;
$1985 \mathrm{~b} ; 1986 ; 1987 ; 1988 ; 1994 ; 1997 ; 2000 \mathrm{a} ; 2000 \mathrm{~b}$; 2001; Aversa et al., 2017a; 2017b; 2017c; 2017d; 2017e; 2016a; 2016b; 2016c; 2016d; 2016e; 2016f; 2016g; 2016h; 2016i; 2016j; 2016k; 2016l; 2016m; 2016n; 2016o; Cao et al., 2013; Dong et al., 2013; Comanescu, 2010; Franklin, 1930; He et al., 2013; Lee, 2013; Lin et al., 2013; Liu et al., 2013; Padula and Perdereau, 2013; Perumaal and Jawahar, 2013; Petrescu, 2011; 2015a; 2015b; Petrescu and Petrescu, 1995a; 1995b; 1997a; 1997b; 1997c; 2000a; 2000b; 2002a; 2002b; 2003; 2005a; $2005 \mathrm{~b}$; 2005c; 2005d; 2005e; 2011a; 2011b; 2012a; $2012 \mathrm{~b} ; 2013 \mathrm{a}$; 2013b; 2013c; 2013d; 2013e; 2016a; 2016b; 2016c; Petrescu et al., 2009; 2016; 2017a; 2017b; 2017c; 2017d; 2017e; 2017f; 2017g; 2017h; 2017i; 2017j; 2017k; 2017l; 2017m; 2017n; 2017o; 2017p; 2017q; $2017 \mathrm{r} ; 2017 \mathrm{~s} ; 2017 \mathrm{t} ; 2017 \mathrm{u} ; 2017 \mathrm{v} ; 2017 \mathrm{w} ; 2017 \mathrm{x}$; 2017y; 2017z; 2017aa; 2017ab; 2017ac; 2017ad; 2017ae; 2018a; 2018b; 2018c; 2018d; 2018e; 2018f; 2018g; 2018h; 2018i; 2018j; 2018k; 2018l; 2018m; 2018n).

\section{Materials and Methods}

The Peugeot Citroën Group in 2006 built a 4-valve hybrid engine with 4 cylinders the first cam opens the normal valve and the second with the phase shift. Almost all current models have stabilized at four valves per cylinder to achieve a variable distribution. In 1971, K. Hain proposes a method of optimizing the cam mechanism to obtain an optimal (maximum) transmission angle and a minimum acceleration at the output. In 1979, F. Giordano investigates the influence of measurement errors in the kinematic analysis of the camel.

In 1985, P. Antonescu presented an analytical method for the synthesis of the cam mechanism and the flat barbed wire and the rocker mechanism. In 1988, J. Angeles and C. Lopez-Cajun presented the optimal synthesis of the cam mechanism and oscillating plate stick. In 2001 Dinu Taraza analyzes the influence of the cam profile, the variation of the angular speed of the distribution shaft and the power, load, consumption and emission parameters of the internal combustion engine. In 2005, Petrescu and Petrescu, present a method of synthesis of the rotating camshaft profile with rotary or rotatable tappet, flat or roller, in order to obtain high yields at the exit.

In the paper (Wiederrich and Roth, 1974), there is presented a basic, single-degree, dual-spring model with double internal damping for simulating the motion of the cam and punch mechanism. In the paper (Fawcett and Fawcett, 1974) is presented the basic dynamic model of a cam mechanism, stick and valve, with two degrees of freedom, without internal damping. A dynamic model with both damping in the system, 
external (valve spring) and internal one is the one presented in the paper (Jones and Reeve, 1974).

A dynamic model with a degree of freedom, generalized, is presented in the paper (Tesar and Matthew, 1974), in which there is also presented a twodegree model with double damping.

In the paper (Sava, 1970) is proposed a dynamic model with 4 degrees of freedom, obtained as follows: The model has two moving masses these by vertical vibration each impose a degree of freedom one mass is thought to vibrate and transverse, generating yet another degree of freedom and the last degree of freedom is generated by the torsion of the camshaft. Also in the paper (Sava, 1970) is presented a simplified dynamic model, amortized. In (Sava, 1970) there is also showed a dynamic model, which takes into account the torsional vibrations of the camshaft.

In the paper (Koster, 1974) a four-degree dynamic model with a single oscillating motion mass is presented, representing one of four degrees of freedom. The other three freedoms result from a torsional deformation of the camshaft, a vertical bending (z), camshaft and a bending strain of the same shaft, horizontally (y), all three deformations, in a plane perpendicular to the axis of rotation. The sum of the momentary efficiency and the momentary losing coefficient is 1 . The work is especially interesting in how it manages to transform the four degrees of freedom into one, ultimately using a single equation of motion along the main axis. The dynamic model presented can be used wholly or only partially, so that on another classical or new dynamic model, the idea of using deformations on different axes with their cumulative effect on a single axis is inserted.
In works (Antonescu et al., 1987; Petrescu and Petrescu, 2005a) there is presented a dynamic model with a degree of freedom, considering the internal damping of the system (c), the damping for which is considered a special function. More precisely, the damping coefficient of the system (c) is defined as a variable parameter depending on the reduced mass of the mechanism ( $m^{*}$ or $J_{\text {reduced }}$ ) and time, i.e., $c$, depends on the time derivative of $m_{\text {reduced }}$. The equation of differential movement of the mechanism is written as the movement of the valve as a dynamic response.

Starting from the kinematic scheme of the classical distribution mechanism (Fig. 1), the dynamic, monodynamic (single degree), translatable, variable damping model (Fig. 2) is constructed, the motion equation of which is:

$M \cdot \ddot{x}=K \cdot(y-x)-k \cdot x-c \cdot \dot{x}-F_{0}$

Equation (1) is nothing else than the equation of Newton, in which the sum of forces on an element in a certain direction $(\mathrm{x})$ is equal to zero.

The notations in formula (1) are as follows:

- $\quad M$ - mass of the reduced valve mechanism

- $K$ - reduced elastic constants of the kinematic chain (rigidity of the kinematic chain)

- $\quad k$ - elastic spring valve constant

- $\quad c$ - the damping coefficient of the entire kinematic chain (internal damping of the system)

- $F, F_{t}$ - the elastic spring force of the valve spring

- $x$ - actual valve displacement (the cam profile) reduced to the axis of the valve

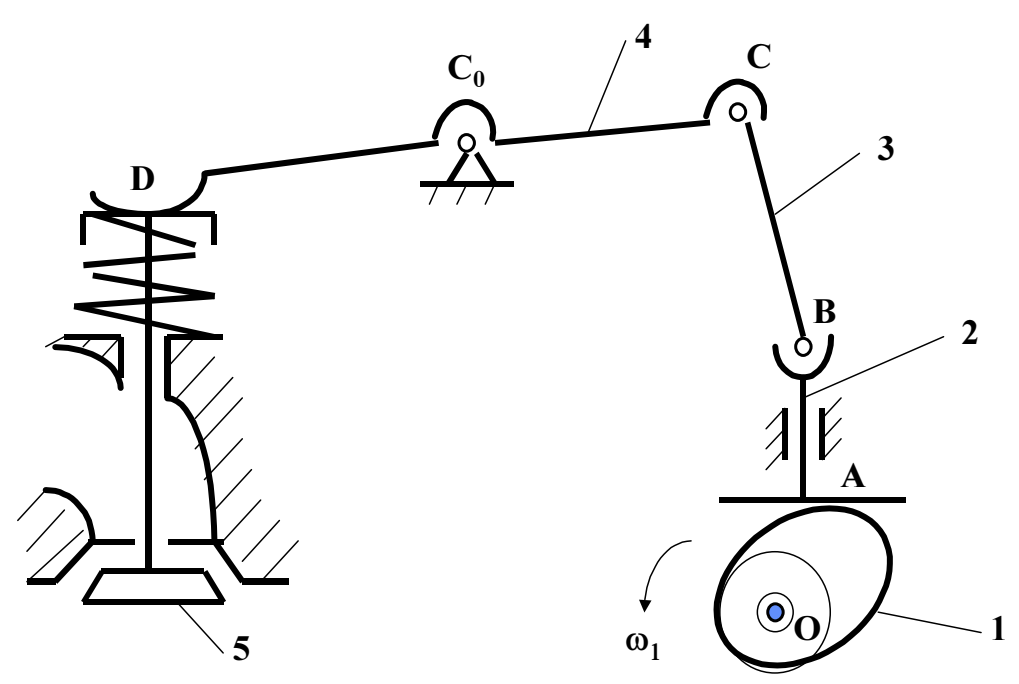

Fig. 1: The kinematic scheme of the classic distribution mechanism 


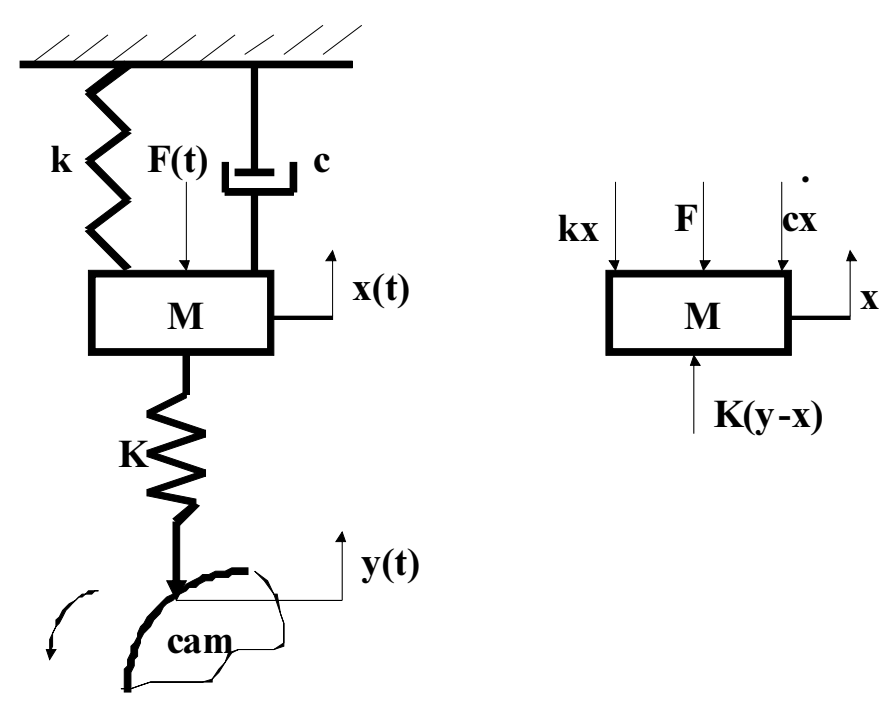

Fig. 2: Mono - dynamic model, with internal depreciation of the variable system

The Newton Equation (1) is ordered as follows:

$M \cdot \ddot{x}+c \cdot \dot{x}=K \cdot(y-x)-\left(F_{0}+k \cdot x\right)$

At the same time the differential equation of the mechanism is also written as Lagrange, (3), (Lagrange equation):

$M \cdot \ddot{x}+\frac{1}{2} \frac{d M}{d t} \cdot \dot{x}=F_{m}-F_{r}$

Equation (3), which is nothing other than the Lagrange differential equation, allows for the low strength of the valve (4) to be obtained by the polynomial coefficients with those of the Newtonian polynomial (2), the reduced drive force at the valve (5), as well as the expression of $c$, i.e., the expression of the internal damping coefficient, of the system (6):

$$
\begin{aligned}
& F_{r}=F_{0}+k \cdot x=k \cdot x_{0}+k \cdot x=k \cdot\left(x_{0}+x\right) \\
& F_{m}=K \cdot(y-x)=K \cdot(s-x) \\
& c=\frac{1}{2} \cdot \frac{d M}{d t}
\end{aligned}
$$

Thus a new formula (6) is obtained, in which the internal damping coefficient (of a dynamic system) is equal to half the derivative with the time of the reduced mass of the dynamic system.

The Newton motion Equation (1, or 2), by replacing it with $\mathrm{c}$ takes the form (7):

$$
M \cdot \ddot{x}+\frac{1}{2} \frac{d M}{d t} \cdot \dot{x}+(K+k) \cdot x=K \cdot y-F_{0}
$$

In the case of the classical distribution mechanism (in Figure 1), the reduced mass, $M$, is calculated by the formula (8):

$$
M=m_{5}+\left(m_{2}+m_{3}\right) \cdot\left(\frac{\dot{y}_{2}}{\dot{x}}\right)^{2}+J_{1} \cdot\left(\frac{\omega_{1}}{\dot{x}}\right)^{2}+J_{4} \cdot\left(\frac{\omega_{4}}{\dot{x}}\right)^{2}
$$

Formula in which or used the following notations:

$m_{2}=$ Stick weight

$m_{3}=$ The mass of the pushing rod

$m_{5}=$ Mass of the valve

$J_{1}=$ Moment of mechanical inertia of the cam

$J_{4}=$ Moment of mechanical inertia of the culbutor

$\dot{y}_{2}=$ Velocity of stroke imposed by cam law

$\dot{\mathrm{x}}=$ Valve speed

If $i=i_{25}$, the valve-to-valve ratio (made by the crank lever), the theoretical velocity of the valve (imposed by the motion law given by the cam profile) is calculated by the formula (9):

$$
y \equiv \dot{y}_{5}=\frac{\dot{y}_{2}}{i}
$$

where:

$i=\frac{C C_{0}}{C_{0} D}$

is the ratio of the crank arms.

The following relationships are written (11-16):

$\dot{x}=\omega_{1} \cdot x^{\prime}$ 


$$
\begin{aligned}
& \ddot{x}=\omega_{1}^{2} \cdot x " \\
& \dot{y}_{2}=\omega_{1} \cdot y_{2}^{\prime}=\omega_{1} \cdot i \cdot y^{\prime} \\
& \frac{\omega_{1}}{\dot{x}}=\frac{\omega_{1}}{\omega_{1} \cdot x^{\prime}}=\frac{1}{x^{\prime}} \\
& \omega_{4}=\frac{\dot{y}_{2}}{C C_{0}}=\frac{\omega_{1} \cdot y_{2}^{\prime}}{C C_{0}}=\frac{\omega_{1} \cdot y^{\prime} \cdot i}{C C_{0}}=\frac{\omega_{1} \cdot y^{\prime}}{C C_{0}} \frac{C C_{0}}{C_{0} D}=\frac{\omega_{1} \cdot y^{\prime}}{C_{0} D} \\
& \frac{\omega_{4}}{\dot{x}}=\frac{\omega_{1} \cdot y^{\prime}}{C_{0} D \cdot \omega_{1} \cdot x^{\prime}}=\frac{1}{C_{0} D} \frac{y^{\prime}}{x^{\prime}}
\end{aligned}
$$

where, $y^{\prime}$ is the reduced velocity imposed by the camshaft (by the law of camshaft movement), reduced to the valve axis.

With the previous relationships (10), (13), (14), (16), the relationship (8) becomes (17-19):

$$
M=m_{5}+\left(m_{2}+m_{3}\right) \cdot\left(\frac{i \cdot y^{\prime}}{x^{\prime}}\right)^{2}+J_{1} \cdot\left(\frac{1}{x^{\prime}}\right)^{2}+J_{4} \cdot\left(\frac{1}{C_{0} D} \frac{y^{\prime}}{x^{\prime}}\right)^{2}
$$

Or:

$$
M=m_{5}+\left[i^{2} \cdot\left(m_{2}+m_{3}\right)+\frac{J_{4}}{\left(C_{0} D\right)^{2}}\right] \cdot\left(\frac{y^{\prime}}{x^{\prime}}\right)^{2}+J_{1} \cdot\left(\frac{1}{x^{\prime}}\right)^{2}
$$

Or:

$M=m_{5}+m^{*} \cdot\left(\frac{y^{\prime}}{x^{\prime}}\right)^{2}+J_{1} \cdot\left(\frac{1}{x^{\prime}}\right)^{2}$

One makes the derivative $\mathrm{dM} / \mathrm{d} \varphi$ and result the following relationships:

$$
\begin{aligned}
& \frac{d\left[\left(\frac{y^{\prime}}{x^{\prime}}\right)^{2}\right]}{d \varphi}=\frac{2 \cdot y^{\prime}}{x^{\prime}} \cdot \frac{\left(y^{\prime \prime} \cdot x^{\prime}-x^{\prime \prime} \cdot y^{\prime}\right)}{x^{\prime 2}} \\
& =\frac{2 \cdot y^{\prime}}{x^{\prime 2}} \cdot\left(y^{\prime \prime}-x^{\prime \prime} \cdot \frac{y^{\prime}}{x^{\prime}}\right)=2 \cdot\left(\frac{y^{\prime}}{x^{\prime}}\right)^{2} \cdot\left(\frac{y^{\prime \prime}}{y^{\prime}}-\frac{x^{\prime \prime}}{x^{\prime}}\right) \\
& \frac{d\left[\left(\frac{1}{x^{\prime}}\right)^{2}\right]}{d \varphi}=\frac{2}{x^{\prime}} \cdot \frac{-x^{\prime \prime}}{x^{\prime 2}}=-2 \cdot \frac{x^{\prime \prime}}{x^{\prime 3}} \\
& \frac{d M}{d \varphi}=2 \cdot m^{*} \cdot\left(\frac{y^{\prime}}{x^{\prime}}\right)^{2} \cdot\left(\frac{y^{\prime \prime}}{y^{\prime}}-\frac{x^{\prime \prime}}{x^{\prime}}\right)-2 \cdot J_{1} \cdot \frac{x^{\prime \prime}}{x^{\prime 3}}
\end{aligned}
$$

Write the relationship (6) as (23): $c=\frac{\omega}{2} \cdot \frac{d M}{d \varphi}$

With (22), relation (23) becomes (24-25):

$$
\begin{aligned}
& c=\omega \cdot\left\{\left[i^{2} \cdot\left(m_{2}+m_{3}\right)+\frac{J_{4}}{\left(C_{0} D\right)^{2}}\right] .\right. \\
& \left.\left(\frac{y^{\prime}}{x^{\prime}}\right)^{2} \cdot\left(\frac{y^{\prime \prime}}{y^{\prime}}-\frac{x^{\prime \prime}}{x^{\prime}}\right)-J_{1} \cdot \frac{x^{\prime \prime}}{x^{\prime 3}}\right\}
\end{aligned}
$$

Or:

$c=\omega \cdot\left[m^{*} \cdot\left(\frac{y^{\prime}}{x^{\prime}}\right)^{2} \cdot\left(\frac{y^{\prime \prime}}{y^{\prime}}-\frac{x^{\prime \prime}}{x^{\prime}}\right)-J_{1} \cdot \frac{x^{\prime \prime}}{x^{\prime 3}}\right]$

Where was noted:

$$
m^{*}=i^{2} \cdot\left(m_{2}+m_{3}\right)+\frac{J_{4}}{\left(C_{0} D\right)^{2}}
$$

With relations (19), (12), (25) and (11), Equation (2) is written first in the form (27), which develops in forms (28), (29) and (30):

$M \cdot \omega^{2} \cdot x^{\prime \prime}+c \cdot \omega \cdot x^{\prime}+(K+k) \cdot x=K \cdot y-F_{0}$

$\left\{\begin{array}{l}\omega^{2} \cdot x^{\prime \prime} \cdot m_{5}+\omega^{2} \cdot m * \cdot\left(\frac{y^{\prime}}{x^{\prime}}\right)^{2} \cdot x^{\prime \prime} \\ +J_{1} \cdot\left(\frac{1}{x^{\prime}}\right)^{2} \cdot x^{\prime \prime} \cdot \omega^{2}+\omega^{2} \cdot x^{\prime} \cdot m^{*} \cdot\left(\frac{y^{\prime}}{x^{\prime}}\right)^{2} \cdot\left(\frac{y^{\prime \prime}}{y^{\prime}}-\frac{x^{\prime \prime}}{x^{\prime}}\right) \\ -x^{\prime} \cdot \omega^{2} \cdot J_{1} \cdot \frac{x^{\prime \prime}}{x^{\prime 3}}+(K+k) \cdot x=K \cdot y-F_{0}\end{array}\right.$

Meaning:

$$
\begin{aligned}
& \omega^{2} \cdot m_{5} \cdot x^{\prime \prime}+\omega^{2} \cdot m^{*} \cdot x^{\prime \prime} \cdot\left(\frac{y^{\prime}}{x^{\prime}}\right)^{2}-\omega^{2} \cdot m^{*} \cdot\left(\frac{y^{\prime}}{x^{\prime}}\right)^{2} \cdot x^{\prime \prime} \\
& +\omega^{2} \cdot m^{*} \cdot y^{\prime \prime} \cdot \frac{y^{\prime}}{x^{\prime}}+(K+k) \cdot x=K \cdot y-F_{0}
\end{aligned}
$$

And final form:

$\omega^{2} \cdot m_{5} \cdot x^{\prime \prime}+(K+k) \cdot x+\omega^{2} \cdot m^{*} \cdot y^{\prime \prime} \cdot \frac{y^{\prime}}{x^{\prime}}=K \cdot y-F_{0}$

which can also be written in another form:

$\omega^{2} \cdot\left(m_{5} \cdot x^{\prime \prime}+m^{*} \cdot y^{\prime \prime} \cdot \frac{y^{\prime}}{x^{\prime}}\right)+(K+k) \cdot x=K \cdot y-F_{0}$ 
Equation (31) can be approximated to form (32) if we consider the theoretical input velocity y imposed by the camshaft profile (reduced to the valve axis) approximately equal to the velocity of the valve, $x$ :

$$
\omega^{2} \cdot\left(m_{5} \cdot x^{\prime \prime}+m^{*} \cdot y^{\prime \prime}\right)+(K+k) \cdot x=K \cdot y-F_{0}
$$

If the laws of entry with $s, s^{\prime}$ (low speed), $s^{\prime \prime}$ (low acceleration), Equation (32) takes the form (33) and the more complete Equation (31) takes the complex form (34):

$$
\begin{aligned}
& \omega^{2} \cdot\left(m_{5} \cdot x^{\prime \prime}+m^{*} \cdot s^{\prime \prime}\right)+(K+k) \cdot x=K \cdot s-F_{0} \\
& \omega^{2} \cdot\left(m_{5} \cdot x^{\prime \prime}+m^{*} \cdot s^{\prime \prime} \cdot \frac{s^{\prime}}{x^{\prime}}\right)+(K+k) \cdot x=K \cdot s-F_{0}
\end{aligned}
$$

In the paper (Antonescu et al., 1985a) there is presented a dynamic damping model variable as in the previous paragraph, but with four degrees of mobility.

The hypothesis of the existence of four masses in translational motion is made at the same time (Fig. 3). Figure $3 \mathrm{a}$ shows the kinematic diagram of the classic distribution mechanism and in Fig. $3 b$ is shown the corresponding dynamic pattern, with four moving masses, thus with four degrees of freedom.

The way in which the four dynamic masses and the corresponding elastic constants, as well as the corresponding damping, are deduced will be presented in the following paragraph. The dynamic model with four degrees of freedom (Fig. 3) is considered, where the four reduced masses of the driven element (valve) are calculated with the formulas (35).

The mass $m_{1} *$ is calculated as the mass $m_{1}$ (mass of the camshaft) that reduces to the valve axis, that is, this mass $m_{1}$, multiplies by the theoretical input speed $\dot{y}_{1 \mathrm{c}}$, square and is divided by the square of the valve speed $\dot{\mathrm{x}}^{2}$, the ratio between the cam entry speed $\dot{\mathrm{y}}_{\mathrm{lc}}$ and valve velocity $\dot{\mathrm{x}}$ and rises to square and this square ratio multiplies by the mass $m_{1}$.

As the input speed $\dot{y}_{1 c}$ must also be reduced to the axis of the valve, instead of it write down the reduced input velocity to the valve axis $\dot{y}_{1}$, multiplied by the coulter transmission ratio, $i$, that is, we have the relation $\dot{\mathrm{y}}_{\mathrm{lc}}=i$. $\dot{\mathrm{y}}_{1}$ and the square velocity $\dot{y}_{1 c}^{2}$, will be replaced with $i^{2} \cdot \dot{y}_{1}^{2}$ and will be written down $\mathrm{i}^{2}$ multiplied to the mass $\mathrm{m}_{1}$ with $m_{1}{ }^{\prime}$. For mass $m_{2}{ }^{*}$, consider the weight of the tappet, $m_{2}$, plus one third of the weight of the pushing rod, $m_{3}$ and the corresponding speed $\dot{y}_{2}$ is practically the dynamic velocity of the tappet reduced to the axis of the valve.

The mass $m_{3}{ }^{*}$ corresponds to the pusher rod and consists of two remaining thirds of the pushing rod weight, $m_{3}$, plus half of the mass of the stem, $\mathrm{m}_{4}$; velocity $\dot{y}_{3}$ is the actual average speed with which the pushing rod moves on the vertical axis reduced to the valve axis, or the speed of the stopper at the point $C$ reduced to the valve axis.

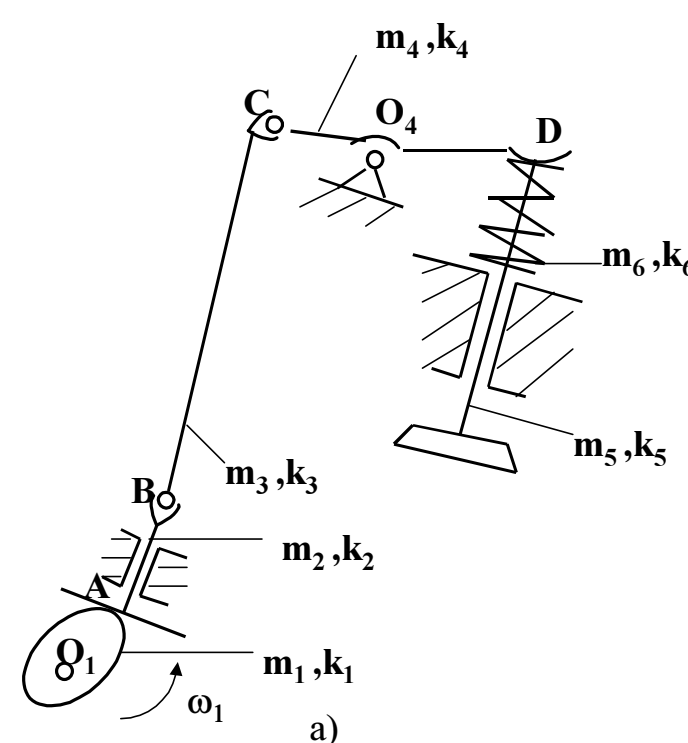

a)

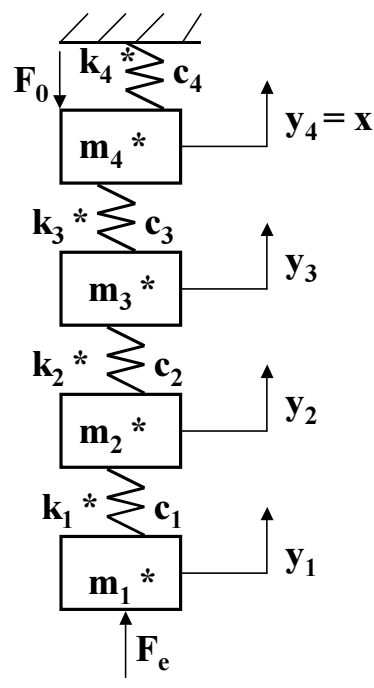

b)

Fig. 3: Dynamic model with four degrees of freedom with internal system damping - variable 
The mass $m_{4} *$ is obtained from all the summaries on the side of the valve, i.e., half the mass of the valve, plus the mass $\mathrm{m}_{5}$ (which in turn represents the sum of the valve mass and the mass of the valve pan) plus a third of the mass of the valve spring. The speed of the valve (obviously at its axis) was marked with $\square$ :

$$
\left\{\begin{array}{l}
m_{1}^{*}=m_{1} \cdot i^{2} \cdot\left(\frac{\dot{y}_{1}}{\dot{x}}\right)^{2}=m_{1}^{\prime} \cdot\left(\frac{\dot{y}_{1}}{\dot{x}}\right)^{2} ; m_{2}^{*} \\
=\left(m_{2}+\frac{1}{3} \cdot m_{3}\right) \cdot i^{2} \cdot\left(\frac{\dot{y}_{2}}{\dot{x}}\right)^{2}=m_{2} \cdot\left(\frac{\dot{y}_{2}}{\dot{x}}\right)^{2} ; \\
m_{3}^{*}=\left(\frac{2}{3} \cdot m_{3}+\frac{1}{2} \cdot m_{4}\right) \cdot i^{2} \cdot\left(\frac{\dot{y}_{3}}{\dot{x}}\right)^{2} \\
=m_{3}^{\prime} \cdot\left(\frac{\dot{y}_{3}}{\dot{x}}\right)^{2} ; m_{4}^{*}=\frac{1}{2} \cdot m_{4}+m_{5}+\frac{1}{3} \cdot m_{6}=m_{4}^{\prime}
\end{array}\right.
$$

where, $i=\mathrm{O}_{4} \mathrm{C} / \mathrm{O}_{4} \mathrm{D}$ (Fig. 3) represents the transmission ratio of the culbutor; $m_{1}, m_{2}, m_{3}, m_{4}, m_{5}, m_{6}$ are in order: The mass of the cam, the stick, the pusher rod, the stem, the valve (with the roller) and the valve spring respectively. The following equivalent elastic constants (Fig. 3) are reduced to the valve (36):

$K_{1}^{*}=\frac{K_{1} \cdot K_{2}}{K_{1}+K_{2}} \cdot i^{2} ; K_{2}^{*}=K_{3} \cdot i^{2} ; K_{3}^{*}=K_{4} ; K_{4}^{*}=K_{6}$

where, $k_{1}, k_{2}, k_{3}, k_{4}, k_{6}$ are the stiffnesses (elastic constants) of the corresponding elements. The elastic valve constant is not in question. It is noted that $F_{0}$ is the external force, known as the spring force of the valve spring and $F_{e}$ is the balancing force at the valve, basically the driving force. The influence of moments of mechanical inertia (mass), weight forces and friction forces will be neglected. Following the dynamic equilibrium for each reduced mass in part are written four equations of the form (37-40):

$$
\begin{aligned}
& K_{1}^{*} \cdot\left(y_{1}-y_{2}\right)-F_{e}+m_{1}^{*} \cdot \ddot{y}_{1}+c_{1} \cdot \dot{y}_{1}=0 \\
& K_{2}^{*} \cdot\left(y_{2}-y_{3}\right)-K_{1}^{*} \cdot\left(y_{1}-y_{2}\right)+m_{2}^{*} \cdot \ddot{y}_{2}+c_{2} \cdot \dot{y}_{2}=0 \\
& K_{3}^{*} \cdot\left(y_{3}-x\right)-K_{2}^{*} \cdot\left(y_{2}-y_{3}\right)+m_{3}^{*} \cdot \ddot{y}_{3}+c_{3} \cdot \dot{y}_{3}=0 \\
& K_{4}^{*} \cdot x-K_{3}^{*} \cdot\left(y_{3}-x\right)+F_{0}+m_{4}^{*} \cdot \ddot{x}+c_{4} \cdot \dot{x}=0
\end{aligned}
$$

The linear displacements $y_{1}, y_{2}, y_{3}, y_{4}=x$ correspond to the reduced masses $m_{1}^{*}, m_{2}^{*}, m_{3}^{*}, m_{4}{ }^{*}$.

Assuming that the movement $y_{1}$ is known from the motion law $y_{1}=y_{1}(\varphi)$ imposed on the camshaft at the cam design, the displacements $y_{2}, y_{3}, x$ and the balance force $F_{e}$, i.e., the motor force $F_{m}$, remain unknown.
In this case it is observed that Equations (38), (39) and (40) form a system of three equations with three unknowns $y_{2}, y_{3}, x$. After calculating the three displacements from (37), the equilibration force $F_{e}$ is obtained.

Basically, the system is not linear because, in addition to the unknowns given by the three displacements, we have as extra unknown the speeds and accelerations derived from unknown movements, i.e., practically unknown will be ten and only four of the system's equations:

$$
c=\frac{1}{2} \cdot \frac{d M}{d t}=\frac{\omega_{1}}{2} \cdot \frac{d M}{d \phi}
$$

For the actual solution of the equation system (37) (40), the damping coefficients $c_{1}, c_{2}, c_{3}, c_{4}$ of formula (41), already known from the system with a degree of freedom and the mass system (35), as follows (42-45):

$$
\begin{aligned}
& c_{1}=\frac{1}{2} \cdot \frac{d m_{1}^{*}}{d t}=m_{1}^{\prime} \cdot\left(\frac{\dot{y}_{1} \cdot \ddot{y}_{1}}{\dot{x}^{2}}-\frac{\dot{y}_{1}^{2} \ddot{x}}{\dot{x}^{3}}\right) \\
& c_{2}=\frac{1}{2} \cdot \frac{d m_{2}^{*}}{d t}=m_{2}^{\prime} \cdot\left(\frac{\dot{y}_{2} \cdot \ddot{y}_{2}}{\dot{x}^{2}}-\frac{\dot{y}_{2}^{2} \cdot \ddot{x}}{\dot{x}^{3}}\right) \\
& c_{3}=\frac{1}{2} \cdot \frac{d m_{3}^{*}}{d t}=m_{3}^{\prime} \cdot\left(\frac{\dot{y}_{3} \cdot \ddot{y}_{3}}{\dot{x}^{2}}-\frac{\dot{y}_{3}^{2} \cdot \ddot{x}}{\dot{x}^{3}}\right) \\
& c_{4}=\frac{1}{2} \cdot \frac{d m_{4}^{*}}{d t}=0
\end{aligned}
$$

which can also be written in the form (46-49):

$$
\begin{aligned}
& c_{1}=m_{1}^{\prime} \cdot\left(\frac{\dot{y}_{1}}{\dot{x}}\right)^{2} \cdot\left(\frac{\ddot{y}_{1}}{\dot{y}_{1}}-\frac{\ddot{x}}{\dot{x}}\right) \\
& c_{2}=m_{2}^{\prime} \cdot\left(\frac{\dot{y}_{2}}{\dot{x}}\right)^{2} \cdot\left(\frac{\ddot{y}_{2}}{\dot{y}_{2}}-\frac{\ddot{x}}{\dot{x}}\right) \\
& c_{3}=m_{3}^{\prime} \cdot\left(\frac{\dot{y}_{3}}{\dot{x}}\right)^{2} \cdot\left(\frac{\ddot{y}_{3}}{\dot{y}_{3}}-\frac{\ddot{x}}{\dot{x}}\right) \\
& c_{4}=0
\end{aligned}
$$

Using Relationships (46-49) and System (35), Relationships (50-53) can be obtained immediately:

$$
\begin{aligned}
& c_{1} \cdot \dot{y}_{1}=m_{1}^{\prime} \cdot\left(\frac{\dot{y}_{1}}{\dot{x}}\right)^{2} \cdot\left(\ddot{y}_{1}-\frac{\dot{y}_{1}}{\dot{x}} \cdot \ddot{x}\right)=m_{1}^{*} \cdot\left(\ddot{y}_{1}-\frac{\dot{y}_{1}}{\dot{x}} \cdot \ddot{x}\right) \\
& c_{2} \cdot \dot{y}_{2}=m_{2}^{\prime} \cdot\left(\frac{\dot{y}_{2}}{\dot{x}}\right)^{2} \cdot\left(\ddot{y}_{2}-\frac{\dot{y}_{2}}{\dot{x}} \cdot \ddot{x}\right)=m_{2}^{*} \cdot\left(\ddot{y}_{2}-\frac{\dot{y}_{2}}{\dot{x}} \cdot \ddot{x}\right)
\end{aligned}
$$




$$
\begin{aligned}
& c_{3} \cdot \dot{y}_{3}=m_{3}^{\prime} \cdot\left(\frac{\dot{y}_{3}}{\dot{x}}\right)^{2} \cdot\left(\ddot{y}_{3}-\frac{\dot{y}_{3}}{\dot{x}} \cdot \ddot{x}\right)=m_{3}^{*} \cdot\left(\ddot{y}_{3}-\frac{\dot{y}_{3}}{\dot{x}} \cdot \ddot{x}\right) \\
& c_{4} \cdot \dot{y}_{4}=c_{4} \cdot \dot{x}=0
\end{aligned}
$$

Taking into account relations (50-53), Equations (37$40)$ are rewritten as follows (54-57):

$$
\begin{aligned}
& K_{1}^{*} \cdot y_{1}-K_{1}^{*} \cdot y_{2}-F_{e}+2 \cdot m_{1}^{\prime} \cdot\left(\frac{\dot{y}_{1}}{\dot{x}}\right)^{2} \cdot \ddot{y}_{1}-m_{1}^{\prime} \cdot\left(\frac{\dot{y}_{1}}{\dot{x}}\right)^{3} \ddot{x}=0 \\
& -K_{1}^{*} \cdot y_{1}+\left(K_{1}^{*}+K_{2}^{*}\right) \cdot y_{2}-K_{2}^{*} \cdot y_{3} \\
& +2 \cdot m_{2}^{\prime} \cdot\left(\frac{\dot{y}_{2}}{\dot{x}}\right)^{2} \cdot \ddot{y}_{2}-m_{2}^{\prime} \cdot\left(\frac{\dot{y}_{2}}{\dot{x}}\right)^{3} \ddot{x}=0 \\
& -K_{2}^{*} \cdot y_{2}+\left(K_{2}^{*}+K_{3}^{*}\right) \cdot y_{3}-K_{3}^{*} \cdot x \\
& +2 \cdot m_{3}^{\prime} \cdot\left(\frac{\dot{y}_{3}}{\dot{x}}\right)^{2} \cdot \ddot{y}_{3}-m_{3}^{\prime} \cdot\left(\frac{\dot{y}_{3}}{\dot{x}}\right)^{3} \cdot \ddot{x}=0 \\
& -K_{3}^{*} \cdot y_{3}+\left(K_{3}^{*}+K_{4}^{*}\right) \cdot x+m_{4}^{\prime} \cdot \ddot{x}+F_{0}=0
\end{aligned}
$$

With the system of Equations (54-57), the dynamic model shown in Fig. 3 is solved, given that the system is nonlinear and besides the four main unknowns, $y_{2}, y_{3}, x$, $F_{e}$, six more unknown $\dot{y}_{2}, \ddot{y}_{2}, \dot{y}_{3}, \ddot{y}_{3}, \dot{x}, \ddot{x}$. occur, but dependent on each other and also depend on linear displacements, $y_{2}, y_{3}$ and $\mathrm{x}$ respectively.

The system is greatly simplified if we consider the three speeds approximately equal to each other and equal to the known entry speed; In this case, the equation system (54-57) is considerably simplified, taking the form (58-61):

$$
\begin{aligned}
& K_{1}^{*} \cdot y_{1}-K_{1}^{*} \cdot y_{2}-F_{e}+2 \cdot m_{1}^{\prime} \cdot \ddot{y}_{1}-m_{1}^{\prime} \cdot \ddot{x}=0 \\
& -K_{1}^{*} \cdot y_{1}+\left(K_{1}^{*}+K_{2}^{*}\right) \cdot y_{2}-K_{2}^{*} \cdot y_{3}+2 \cdot m_{2}^{\prime} \cdot \ddot{y}_{2}-m_{2}^{\prime} \cdot \ddot{x}=0 \\
& -K_{2}^{*} \cdot y_{2}+\left(K_{2}^{*}+K_{3}^{*}\right) \cdot y_{3}-K_{3}^{*} \cdot x+2 \cdot m_{3}^{\prime} \cdot \ddot{y}_{3}-m_{3}^{\prime} \cdot \ddot{x}=0 \\
& -K_{3}^{*} \cdot y_{3}+\left(K_{3}^{*}+K_{4}^{*}\right) \cdot x+m_{4}^{\prime} \cdot \ddot{x}+F_{0}=0
\end{aligned}
$$

\section{Results and Discussion; SOLVING THE DIFFERENTIAL EQUATION}

In the paper was presented a dynamic model with a degree of mobility, internal damping of the variable system, which finally leads to the Equation (54), which can be writhed in the form (62) and the simplified Equation (53), arranged now in form (63):

$$
\begin{aligned}
& (K+k) \cdot x=K \cdot y-k \cdot x_{0}-\omega^{2} \cdot m_{S} \cdot X^{I I}-\omega^{2} \cdot m_{T} \cdot y^{\prime \prime} \cdot \frac{y^{\prime}}{X^{I}} \\
& (K+k) \cdot x=K \cdot y-k \cdot x_{0}-\omega^{2} \cdot m_{S} \cdot X^{I I}-\omega^{2} \cdot m_{T} \cdot y^{\prime \prime}
\end{aligned}
$$

Differential Equation (63), i.e., the simplified form (in which the reduced input velocity imposed by the cam profile $y^{\prime}$ is equal to the low dynamic velocity, $x^{\prime}$, both reduced to the valve axis) is used.

\section{Solving the Differential Equation, Through a Particular Solution}

Equation (63) is written as (64):

$m_{S} \cdot \ddot{X}+(K+k) \cdot X=K \cdot y-k \cdot x_{0}-m_{T} . \ddot{y}$

One divides Equation (64) with $m_{S}$ and amplify the straight term with $\cos \omega t$, thus obtaining the form (65):

$\ddot{X}+\frac{K+k}{m_{S}} \cdot X=\frac{K \cdot y-k \cdot x_{0}-m_{T} \cdot \ddot{y}}{m_{S} \cdot \cos (\omega \cdot t)} \cdot \cos (\omega \cdot t)$

The following notations (66-67) are used:

$p^{2}=\frac{K+k}{m_{S}}$

$q=\frac{K \cdot y-k \cdot x_{0}-m_{T} \cdot \ddot{y}}{m_{S} \cdot \cos (\omega \cdot t)}$

Equation (65) is written in simplified form (68):

$\ddot{X}+p^{2} \cdot X=q \cdot \cos (\omega \cdot t)$

The particular solution of Equation (68) is of the form (69):

$X=a \cdot \cos (\omega \cdot t)$

Derivatives 1 and 2 of solution (69) are denoted by (70-71):

$\dot{X}=-a . \omega \cdot \sin (\omega . t)$

$\ddot{X}=-a \cdot \omega^{2} \cdot \cos (\omega . t)$

By replacing values (69) and (71) in Equation (68), form (72) is obtained:

$-a \cdot \omega^{2} \cdot \cos (\omega \cdot t)+p^{2} \cdot a \cdot \cos (\omega \cdot t)=q \cdot \cos (\omega \cdot t)$

The characteristic equation is written as (73): 


$$
a \cdot\left(p^{2}-\omega^{2}\right)=q
$$

It is explicit $a$ in the form (74):

$$
a=\frac{q}{p^{2}-\omega^{2}}
$$

Now write the solution $X$, under the forms (75), (76):

$$
\begin{aligned}
& X=\frac{q}{p^{2}-\omega^{2}} \cdot \cos (\omega \cdot t) \\
& X=\frac{K \cdot y-k \cdot x_{0}-m_{T} \cdot \ddot{y}}{m_{S} \cdot \cos (\omega \cdot t)} \cdot \frac{\cos (\omega \cdot t)}{\frac{K+k}{m_{S}}-\omega^{2}}=\frac{K \cdot y-k \cdot x_{0}-m_{T} \cdot \ddot{y}}{K+k-m_{S} \cdot \omega^{2}}
\end{aligned}
$$

For a more exact solution, we approximate directly in Equation (74), $X$ ' cu y' cu s', i.e., $\ddot{X}=\ddot{y}=\ddot{s}$ and one arrives at the linear Equation (77):

$$
X=\frac{K . s-k \cdot x_{0}-\left(m_{S}+m_{T}\right) . \ddot{s}}{K+k}=\frac{K \cdot s-k \cdot x_{0}-m^{*} . \ddot{s}}{K+k}
$$

Solving the Differential Equation, Through a Complete Private Solution

Equation (64) can be written as (78), taking into account coefficients $D$ and $D^{\prime}$ :

$$
\begin{aligned}
& m_{S} \cdot \omega^{2} \cdot D \cdot x^{\prime \prime}+m_{S} \cdot \omega^{2} \cdot D^{\prime} \cdot x^{\prime}+(K+k) \cdot x \\
& =K \cdot s-k \cdot x_{0}-m_{T} \cdot \omega^{2} \cdot\left(D \cdot s^{\prime \prime}+D^{\prime} \cdot s^{\prime}\right)
\end{aligned}
$$

One divides Equation (78) with $m_{S} \cdot \omega^{2} . D$ and obtain the form (79):

$$
\begin{aligned}
& x^{\prime \prime}+\frac{m_{S} \cdot \omega^{2} \cdot D^{\prime}}{m_{S} \cdot \omega^{2} \cdot D} \cdot x^{\prime}+\frac{K+k}{m_{S} \cdot \omega^{2} \cdot D} \cdot x= \\
& \frac{K \cdot s-k \cdot x_{0}-m_{T} \cdot \omega^{2} \cdot\left(D \cdot s^{\prime \prime}+D^{\prime} \cdot s^{\prime}\right)}{m_{S} \cdot \omega^{2} \cdot D}
\end{aligned}
$$

The right term is amplified with $(\cos \varphi+\sin \varphi)$ and Equation (79) is written as (80):

$$
\begin{aligned}
& x^{\prime \prime}+\frac{D^{\prime}}{D} \cdot x^{\prime}+\frac{K+k}{m_{S} \cdot \omega^{2} \cdot D} \cdot x \\
& =\frac{K \cdot s-k \cdot x_{0}-m_{T} \cdot \omega^{2} \cdot\left(D \cdot s^{\prime \prime}+D^{\prime} \cdot s^{\prime}\right)}{m_{S} \cdot \omega^{2} \cdot D \cdot(\cos \varphi+\sin \varphi)} \cdot(\cos \varphi+\sin \varphi)
\end{aligned}
$$

Note the corresponding coefficients (81-83):

$$
a=\frac{D^{\prime}}{D}
$$

$$
b=\frac{K+k}{m_{S} \cdot D \cdot \omega^{2}}
$$

$c=\frac{K \cdot s-k \cdot x_{0}-m_{T} \cdot \omega^{2} \cdot\left(D \cdot s^{\prime \prime}+D^{\prime} \cdot s^{\prime}\right)}{m_{S} \cdot \omega^{2} \cdot D \cdot(\cos \varphi+\sin \varphi)}$

Equation (80) can now be written as (84):

$$
x^{\prime \prime}+a \cdot x^{\prime}+b \cdot x=c \cdot(\cos \varphi+\sin \varphi)
$$

The complete particular solution of Equation (84) is of the form (85) and its derivatives according to the angle $\varphi$, the derivatives I and II, take the forms (86), respectively (87):

$$
\begin{aligned}
& x=A \cdot \cos \varphi+B \cdot \sin \varphi \\
& x^{\prime}=-A \cdot \sin \varphi+B \cdot \cos \varphi \\
& x^{\prime \prime}=-A \cdot \cos \varphi-B \cdot \sin \varphi
\end{aligned}
$$

Introducing solutions (85-87) in (84) one obtains Equation (88):

$$
\begin{aligned}
& -A \cdot \cos \varphi-B \cdot \sin \varphi-a \cdot A \cdot \sin \varphi+a \cdot B \cdot \cos \varphi \\
& +b \cdot A \cdot \cos \varphi+b \cdot B \cdot \sin \varphi=C \cdot \cos \varphi+C \cdot \sin \varphi
\end{aligned}
$$

One identifies the coefficients in the cosine and those in the $\sin$ and one obtains a linear system of two equations with two unknown, $A$ and $B$ respectively:

$\left\{\begin{array}{l}(b-1) \cdot A+a \cdot B=c \\ -a \cdot A+(b-1) \cdot B=c\end{array}\right.$

For the operative solving of the system (89) the first equation increases with $a$ and the second with $(b-1)$, after which $B$ is collected and then determined by $A$, multiplying the first equation with $(b-1)$ and the second one with $-\mathrm{a}$, after which it collects and obtains the system (90):

$$
\left\{\begin{array}{l}
A=\frac{c}{a^{2}+(b-1)^{2}} \cdot(b-1-a) \\
B=\frac{c}{a^{2}+(b-1)^{2}} \cdot(b-1+a)
\end{array}\right.
$$

The solution can now be written as (91), where the coefficients $a, b, c$ are known (81-83):

$x=\frac{c}{a^{2}+(b-1)^{2}} \cdot[(b-1-a) \cdot \cos \varphi+(b-1+a) \cdot \sin \varphi]$ 
Solving the Differential Equation, with the Help of Taylor Series Developments

Write the relation (92), which expresses the connection between the dynamic displacement of the valve, $x$ and that imposed by the cam profile, s:

$$
x(\varphi)=s(\varphi)+\Delta x(\varphi) \cong s(\varphi+\Delta \varphi)
$$

The function $s(\varphi+\Delta \varphi)$ was developed in a Taylor series and retains the first 8 terms of development; now find the relationship (93):

$$
\begin{aligned}
& x=s(\varphi+\Delta \varphi)=\frac{1}{0 !} s(\varphi) \cdot(\Delta \varphi)^{0}+\frac{1}{1 !} s^{I}(\varphi) \cdot \Delta \varphi \\
& +\frac{1}{2 !} s^{I I}(\varphi) \cdot(\Delta \varphi)^{2}+\frac{1}{3 !} \cdot s^{I I I}(\varphi) \cdot(\Delta \varphi)^{3}+\frac{1}{4 !} \cdot s^{I V}(\varphi) \cdot(\Delta \varphi)^{4} \\
& +\frac{1}{5 !} \cdot s^{V}(\varphi) \cdot(\Delta \varphi)^{5}+\frac{1}{6 !} \cdot s^{I I}(\varphi) \cdot(\Delta \varphi)^{6}+\frac{1}{7 !} \cdot s^{V I I}(\varphi) \cdot(\Delta \varphi)^{7}
\end{aligned}
$$

The relationship (93) is also written in the form (94):

$$
\begin{aligned}
& x=s+s^{I} \cdot \Delta \varphi+\frac{1}{2} \cdot s^{I I} \cdot(\Delta \varphi)^{2}+\frac{1}{6} \cdot s^{I I I} \cdot(\Delta \varphi)^{3}+\frac{1}{24} \cdot s^{I V} \cdot(\Delta \varphi)^{4} \\
& +\frac{1}{120} \cdot s^{V} \cdot(\Delta \varphi)^{5}+\frac{1}{720} \cdot s^{V I} \cdot(\Delta \varphi)^{6}+\frac{1}{5040} \cdot s^{V I I} \cdot(\Delta \varphi)^{7}
\end{aligned}
$$

By derivation it obtains $x^{\prime}$ (relation 95):

$$
\begin{aligned}
& x^{I}=s^{I}+s^{I I} \cdot \Delta \varphi+\frac{1}{2} \cdot s^{I I I} \cdot(\Delta \varphi)^{2}+\frac{1}{6} \cdot s^{I V} \cdot(\Delta \varphi)^{3}+\frac{1}{24} \cdot s^{V} . \\
& (\Delta \varphi)^{4}+\frac{1}{120} \cdot s^{V I} \cdot(\Delta \varphi)^{5}+\frac{1}{720} \cdot s^{I I I} \cdot(\Delta \varphi)^{6}+\frac{1}{5040} \cdot s^{V I I I} \cdot(\Delta \varphi)^{7}
\end{aligned}
$$

Deriving the second time and get $x^{\prime \prime}$, (relation 96):

$$
\begin{aligned}
& x^{I I}=s^{I I}+s^{I I I} \cdot \Delta \varphi+\frac{1}{2} \cdot s^{I V} \cdot(\Delta \varphi)^{2} \\
& +\frac{1}{6} \cdot s^{V} \cdot(\Delta \varphi)^{3}+\frac{1}{24} \cdot s^{V I} \cdot(\Delta \varphi)^{4} \\
& +\frac{1}{120} \cdot s^{V I I} \cdot(\Delta \varphi)^{5}+\frac{1}{720} \cdot s^{V I I} \cdot(\Delta \varphi)^{6}+\frac{1}{5040} \cdot s^{I X} \cdot(\Delta \varphi)^{7}
\end{aligned}
$$

The differential equation used is (62), i.e., the complete equation, which we write in the form (97), also taking into account the transmission function, $D$ :

$$
\begin{aligned}
& K \cdot s-k \cdot x_{0}-m_{S}^{*} \cdot\left(D \cdot x^{\prime \prime}+D^{\prime} \cdot x^{\prime}\right) \cdot \omega^{2} \cdot 0.001 \\
& x=\frac{-m_{T}^{*} \cdot\left(D \cdot s^{\prime \prime}+D^{\prime} \cdot s^{\prime}\right) \cdot \omega^{2} \cdot 0.001 \cdot \frac{s^{\prime}}{x^{\prime}}}{K+k}
\end{aligned}
$$

Dynamic analysis for sinus law, using the relationship (97), based on Taylor series and dynamicA1 model, with variable internal damping, without considering the mass $\mathrm{m} 1$ of the cam.

Using the relation (97) obtained from the differential Equation (62) based on the dynamic damping model of the variable system, without considering the mass $\mathrm{ml}$ of the cam, but using Taylor series calculations with the retention of 8 consecutive terms, dynamic (A1).

For this dynamic model (A1) there is a single dynamic diagram (Fig. 4).

The SINus law is used, the engine speed, $n=5500$ [rpm], equal ascension and descent angles, $\varphi_{u}=\varphi_{c}=75^{\circ}$, radius of the base circle, $r_{0}=14[\mathrm{~mm}]$. For the maximum stroke of the tappet, $h_{T}$, equal to that of the valve, $h_{S}(i=$ $1)$, the value of $h=5[\mathrm{~mm}]$ was taken. A spring elastic constant is adopted, $k=60[\mathrm{~N} / \mathrm{mm}]$, for a valve spring compression of $x_{0}=30[\mathrm{~mm}]$.

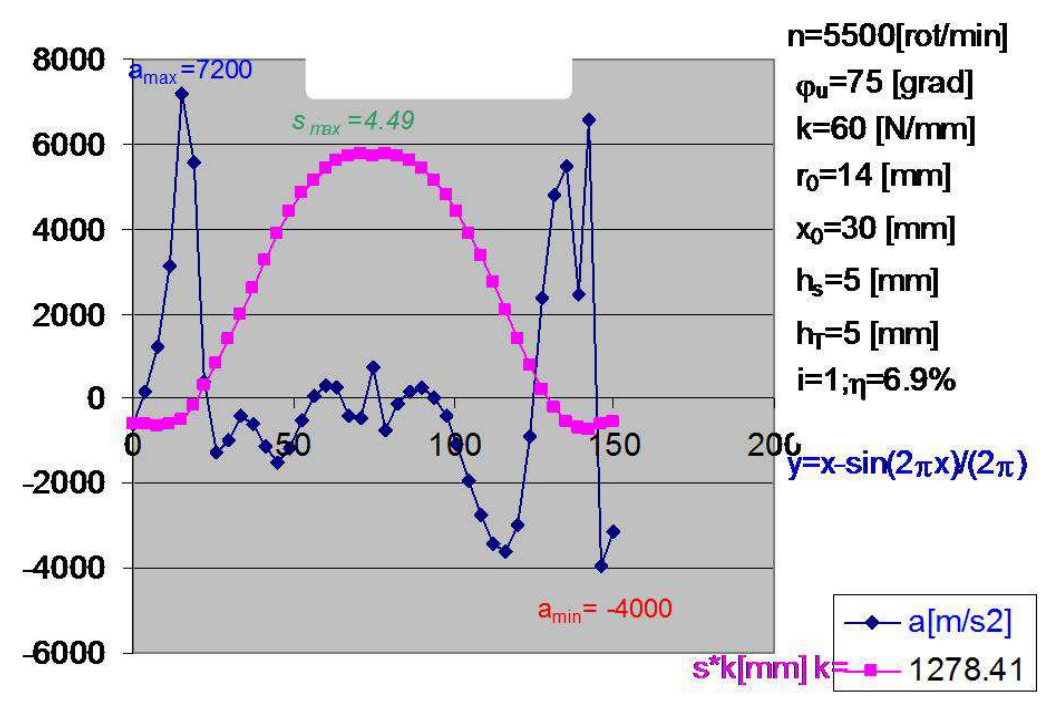

Fig. 4: Dynamic analysis using the dynamic A1 model 
Mechanical yield is low (generally in rotary cam and punch mechanisms, mechanical efficiency has low values and in Module C-classical distribution mechanism these values are even slightly lower), $\eta=6.9 \%$.

The theoretical model presented and used has the advantages of simulating even the fine vibrations of the mechanism.

\section{Conclusion}

The development and diversification of road vehicles and vehicles, especially of cars, together with thermal engines, especially internal combustion engines (being more compact, robust, more independent, more reliable, stronger, more dynamic etc.)., has also forced the development of devices, mechanisms and component assemblies at an alert pace. The most studied are power and transmission trains.

The four-stroke internal combustion engine (fourstroke, Otto or Diesel) comprises in most cases (with the exception of rotary motors) and one or more camshafts, valves, valves and so on.

The classical distribution mechanisms are robust, reliable, dynamic, fast-response and although they functioned with very low mechanical efficiency, taking much of the engine power and effectively causing additional pollution and increased fuel consumption, they could not be abandoned until the present. Another problem was the low speed from which these mechanisms begin to produce vibrations and very high noises.

Regarding the situation realistically, the mechanisms of cam casting and sticking are those that could have produced more industrial, economic, social revolutions in the development of mankind. They have contributed substantially to the development of internal combustion engines and their spreading to the detriment of external combustion (Steam or Stirling) combustion engines.

The problem of very low yields, high emissions and very high power and fuel consumption has been greatly improved and regulated over the past 20-30 years by developing and introducing modern distribution mechanisms that, besides higher yields immediately deliver a high fuel economy) also performs optimal noise-free, vibration-free, no-smoky operation, as the maximum possible engine speed has increased from 6000 to 30000 [rpm].

The paper tries to provide additional support to the development of distribution mechanisms so that their performance and the engines they will be able to further enhance.

Particular performance is the further increase in the mechanical efficiency of distribution systems, up to unprecedented quotas so far, which will bring a major fuel economy.

The paper presents a dynamic model that works with variable internal damping, applicable directly to rigid memory mechanisms. If the problem of elasticity is generally solved, the problem of system damping is not clear and well-established. It is usually considered a constant "c" value for the internal damping of the system and sometimes the same value $\mathrm{c}$ and for the damping of the elastic spring supporting the valve. However, the approximation is much forced, as the elastic spring damping is variable and for the conventional cylindrical spring with constant elasticity parameter $(\mathrm{k})$ with linear displacement with force, the damping is small and can be considered zero. It should be specified that damping does not necessarily mean stopping (or opposition) movement, but damping means energy consumption to brake the motion (rubber elastic elements have considerable damping, as are hydraulic dampers).

Metal helical springs generally have a low (negligible) damping. The braking effect of these springs increases with the elastic constant (the k-stiffness of the spring) and the force of the spring $\left(\mathrm{P}_{0}\right.$ or $\left.\mathrm{F}_{0}\right)$ of the spring (in other words with the arc static arrow, $\left.\mathrm{x}_{0}=\mathrm{P}_{0} / \mathrm{k}\right)$. Energy is constantly changing but does not dissipate (for this reason, the yield of these springs is generally higher).

The paper presents a dynamic model with a degree of freedom, considering internal damping of the system (c), damping for which it is considered a special function. More precisely, the cushioning coefficient of the system (c) is defined as a variable parameter depending on the reduced mass of the mechanism ( $\mathrm{m}^{*}$ or J reduced) and the time, i.e., $\mathrm{c}$ depends on the derivative of $\mathrm{m}$ reduced in time.

The equation of the differential movement of the mechanism is written as the movement of the valve as a dynamic response. Dynamic analysis for sinus law, using the relationship (97), based on Taylor series and dynamic-A1 model, with variable internal damping, without considering the mass $\mathrm{m} 1$ of the cam.

Using the relation (97) obtained from the differential Equation (62) based on the dynamic damping model of the variable system, without considering the mass $\mathrm{m}_{1}$ of the cam, but using Taylor series calculations with the retention of 8 consecutive terms, dynamic (A1). For this dynamic model (A1) there is a single dynamic diagram (Fig. 4).

The SINus law is used, the engine speed, $\mathrm{n}=5500$ [rpm], equal ascension and descent angles, $\varphi_{\mathrm{u}}=\varphi_{\mathrm{c}}=75^{\circ}$, radius of the base circle, $\mathrm{r}_{0}=14[\mathrm{~mm}]$. For the maximum stroke of the tappet, $\mathrm{h}_{\mathrm{T}}$, equal to that of the valve, $\mathrm{h}_{\mathrm{S}}(\mathrm{i}=$ $1)$, the value of $h=5[\mathrm{~mm}]$ was taken. A spring elastic constant is adopted, $\mathrm{k}=60[\mathrm{~N} / \mathrm{mm}]$, for a valve spring compression of $x_{0}=30[\mathrm{~mm}]$.

Mechanical yield is low (generally in rotary cam and punch mechanisms, mechanical efficiency has low values and in Module C-classical distribution mechanism these values are even slightly lower), $\eta=6.9 \%$.

The original theoretical model presented and used has the advantages of simulating even the fine vibrations of the mechanism. 
These kind of mechanisms are used and to the robots of today.

\section{Acknowledgement}

This text was acknowledged and appreciated by Dr. Veturia CHIROIU Honorific member of Technical Sciences Academy of Romania (ASTR) PhD supervisor in Mechanical Engineering.

\section{Funding Information}

Research contract: 1-Research contract: Contract number 36-5-4D/1986 from 24IV1985, beneficiary CNST RO (Romanian National Center for Science and Technology) Improving dynamic mechanisms.

2-Contract research integration. 19-91-3 from 29.03.1991; Beneficiary: MIS; TOPIC: Research on designing mechanisms with bars, cams and gears, with application in industrial robots.

3-Contract research. GR 69/10.05.2007: NURC in 2762; theme 8: Dynamic analysis of mechanisms and manipulators with bars and gears.

4-Labor contract, no. 35/22.01.2013, the UPB, "Stand for reading performance parameters of kinematics and dynamic mechanisms, using inductive and incremental encoders, to a Mitsubishi Mechatronic System" "PN-IIIN-CI-2012-1-0389".

All these matters are copyrighted! Copyrights: 394qodGnhhtej, from 17-02-2010 13:42:18; 463vpstuCGsiy, from 20-03-2010 12:45:30; 631sqfsgqvutm, from 24-05-2010 16:15:22; 933CrDztEfqow, from 07-01-2011 13:37:52.

\section{Ethics}

This article is original and contains unpublished material. Authors declare that are not ethical issues and no conflict of interest that may arise after the publication of this manuscript.

\section{References}

Ab-Rahman, M.S., H. Guna, MH. Harun, SD. Zan and K. Jumari, 2009. Cost-effective fabrication of selfmade $1 \times 12$ polymer optical fiber-based optical splitters for automotive application. Am. J. Eng. Applied Sci., 2: 252-259.

DOI: 10.3844/ajeassp.2009.252.259

Abam, F.I., I.U. Ugot and D.I. Igbong, 2012. Performance analysis and components irreversibilities of a $(25 \mathrm{MW})$ gas turbine power plant modeled with a spray cooler. Am. J. Eng. Applied Sci., 5: 35-41.

DOI: 10.3844 /ajeassp.2012.35.41
Abdelkrim, H., S.B. Othman, A.K.B. Salem and S.B. Saoud, 2012. Dynamic partial reconfiguration contribution on system on programmable chip architecture for motor drive implementation. Am. J. Eng. Applied Sci., 5: 15-24. DOI: 10.3844 /ajeassp.2012.15.24

Abdullah, M.Z., A. Saat and Z. Hamzah, 2011. Optimization of energy dispersive x-ray fluorescence spectrometer to analyze heavy metals in moss samples. Am. J. Eng. Applied Sci., 4: 355-362. DOI: 10.3844/ajeassp.2011.355.362

Abdullah, M., A. F.M. Zain, Y. H. Ho and S. Abdullah, 2009. TEC and scintillation study of equatorial ionosphere: A month campaign over sipitang and parit raja stations, Malaysia. Am. J. Eng. Applied Sci., 2: 44-49. DOI: 10.3844/ajeassp.2009.44.49

Abdullah, H. and S.A. Halim, 2009. Electrical and magnetoresistive studies $\mathrm{Nd}$ doped on La-Ba-Mn-O manganites for low-field sensor application. Am. J. Eng. Applied Sci., 2: 297-303.

DOI: 10.3844 /ajeassp.2009.297.303

Abouobaida, H., 2016. Robust and efficient controller to design a standalone source supplied DC and AC load powered by photovoltaic generator. Am. J. Eng. Applied Sci., 9: 894-901.

DOI: 10.3844 /ajeassp.2016.894.901

Abu-Ein, S., 2009. Numerical and analytical study of exhaust gases flow in porous media with applications to diesel particulate filters. Am. J. Eng. Applied Sci., 2: 70-75.

DOI: 10.3844/ajeassp.2009.70.75

Abu-Lebdeh, M., G. Pérez-de León, S.A. Hamoush, R.D. Seals and V.E. Lamberti, 2016. Gas atomization of molten metal: Part II. Applications. Am. J. Eng. Applied Sci., 9: 334-349. DOI: 10.3844/ajeassp.2016.334.349

Agarwala, S., 2016. A perspective on 3D bioprinting technology: Present and future. Am. J. Eng. Applied Sci., 9: 985-990.

DOI: 10.3844/ajeassp.2016.985.990

Ahmed, M., R. Khan, M. Billah and S. Farhana, 2010. A novel navigation algorithm for hexagonal hexapod robot. Am. J. Eng. Applied Sci., 3: 320-327. DOI: 10.3844 /ajeassp.2010.320.327

Ahmed, M.K., H. Haque and H. Rahman, 2016. An approach to develop a dynamic job shop scheduling by fuzzy rule-based system and comparative study with the traditional priority rules. Am. J. Eng. Applied Sci., 9: 202-212.

DOI: 10.3844 /ajeassp.2016.202.212

Akhesmeh, S., N. Pourmahmoud and H. Sedgi, 2008. Numerical study of the temperature separation in the ranque-hilsch vortex tube. Am. J. Eng. Applied Sci., 1: 181-187. DOI: 10.3844/ajeassp.2008.181.187 
Akubue, A., 2011. Appropriate technology for socioeconomic development in third world countries. J. Technol. Stud., 26: 33-43.

DOI: $10.21061 /$ jots.v26il.a.6

Al-Abbas, I.K., 2009. Reduced order models of a current source inverter induction motor drive. Am. J. Eng. Applied Sci., 2: 39-43.

DOI: 10.3844 /ajeassp.2009.39.43

Al-Hasan and A.S. Al-Ghamdi, 2016. Energy balance for a diesel engine operates on a pure biodiesel, diesel fuel and biodiesel-diesel blends. Am. J. Eng. Applied Sci., 9: 458-465.

DOI: 10.3844/ajeassp.2016.458.465

Al Smadi, T.A., 2011. Low cost smart sensor design. Am. J. Eng. Applied Sci., 4: 162-168. DOI: 10.3844/ajeassp.2011.162.168

Al Qadi, A.N.S., M.B.A. ALhasanat, A. AL Dahamsheh and S. AL Zaiydneen, 2016a. Using of box-benken method to predict the compressive strength of selfcompacting concrete containing Wadi Musa bentonite, Jordan. Am. J. Eng. Applied Sci., 9: 406-411.

DOI: 10.3844/ajeassp.2016.406.411

Al Qadi, A.N.S., M.B.A. Alhasanat and M. Haddad, 2016b. Effect of crumb rubber as coarse and fine aggregates on the properties of asphalt concrete. Am. J. Eng. Applied Sci., 9: 558-564.

DOI: 10.3844/ajeassp.2016.558.564

Aleksic, S. and A. Lovric, 2011. Energy consumption and environmental implications of wired access networks. Am. J. Eng. Applied Sci., 4: 531-539. DOI: 10.3844/ajeassp.2011.531.539

Alhasanat, M.B., A.N. Al Qadi, O.A. Al Khashman and A. Dahamsheh, 2016. Scanning electron microscopic evaluation of self-compacting concrete spalling at elevated temperatures. Am. J. Eng. Applied Sci., 9: 119-127.

DOI: 10.3844/ajeassp.2016.119.127

Ali, K.S. and JL. Shumaker, 2013. Hardware in the loop simulator for multi-agent unmanned aerial vehicles environment. Am. J. Eng. Applied Sci., 6: 172-177. DOI: 10.3844/ajeassp.2013.172.177

Ali, G.A.M., O. Fouad and S.A. Makhlouf, 2016. Electrical properties of cobalt oxide/silica nanocomposites obtained by sol-gel technique. Am.

J. Eng. Applied Sci., 9: 12-16.

DOI: 10.3844 /ajeassp.2016.12.16

Al-Nasra, M. Daoudb and T.M. Abu-Lebdeh, 2015. The use of the super absorbent polymer as water blocker in concrete structures. Am. J. Eng. Applied Sci., 8: 659-665. DOI: 10.3844/ajeassp.2015.659.665

Alwetaishi, M.S., 2016. Impact of building function on thermal comfort: A review paper. Am. J. Eng. Applied Sci., 9: 928-945.

DOI: 10.3844/ajeassp.2016.928.945
Aly, W.M. and M.S. Abuelnasr, 2010. Electronic design automation using object oriented electronics. Am. J. Eng. Applied Sci., 3: 121-127. DOI: 10.3844/ajeassp.2010.121.127

Amani, N., 2016. Design and implementation of optimum management system using cost evaluation and financial analysis for prevention of building failure. Am. J. Eng. Applied Sci., 9: 281-296. DOI: 10.3844 /ajeassp.2016.281.296

Amer, S., S. Hamoush and T.M. Abu-Lebdeh, 2015. Experimental evaluation of the raking energy in damping system of steel stud partition walls. Am. J. Eng. Applied Sci., 8: 666-677. DOI: 10.3844 /ajeassp.2015.666.677

Anizan, S., K. Yusri, C.S. Leong, N. Amin and S. Zaidi et al., 2011. Effects of the contact resistivity variations of the screen-printed silicon solar cell. Am. J. Eng. Applied Sci., 4: 328-331. DOI: 10.3844/ajeassp.2011.328.331

Angeles, J. and C. Lopez-Cajun, 1988. Optimal synthesis of cam mechanisms with oscillating flat-face followers. Mechanism Mach. Theory, 23: 1-6. DOI: $10.1016 / 0094-114 X(88) 90002-X$

Antonescu, P., 2000. Mechanisms and Handlers. 1st Edn., Printech Publishing House, Bucharest.

Antonescu, P. and F.I.T. Petrescu, 1985. An analytical method of synthesis of cam mechanism and flat stick. Proceedings of the 4th International Symposium on Theory and Practice of Mechanisms, (TPM' 85), Bucharest.

Antonescu, P. and F.I.T. Petrescu, 1989. Contributions to cinetoelastodynamic analysis of distribution mechanisms. Bucharest.

Antonescu, P., M. Oprean and F.I.T. Petrescu, 1985a. Contributions to the synthesis of oscillating cam mechanism and oscillating flat stick. Proceedings of the 4th International Symposium on Theory and Practice of Mechanisms, (TPM' 85), Bucharest.

Antonescu, P., M. Oprean and F.I.T. Petrescu, 1985b. At the projection of the oscillate cams, there are mechanisms and distribution variables. Proceedings of the 5th Conference of Engines, Automobiles, Tractors and Agricultural Machines, (AMA' 58), IMotors and Cars, Brasov.

Antonescu, P., M. Oprean and F.I.T. Petrescu, 1986. Projection of the profile of the rotating camshaft acting on the oscillating plate with disengagement. Proceedings of the 3rd National Computer-aided Design Symposium in the field of Mechanisms and Machine Parts, (MMP' 86), Brasov.

Antonescu, P., M. Oprean and F.I.T. Petrescu, 1987. Dynamic analysis of the cam distribution mechanisms. Proceedings of the 7th National Symposium on Industrial Robots and Space Mechanisms, (RSM' 87), Bucharest. 
Antonescu, P., M. Oprean and F.I.T. Petrescu, 1988. Analytical synthesis of Kurz profile, rotating the flat cam. Mach, Build. Rev.

Antonescu, P., F.I.T. Petrescu and O. Antonescu, 1994. Contributions to the synthesis of the rotating cam mechanism and the tip of the balancing tip. Brasov.

Antonescu, P., F.I.T. Petrescu and D. Antonescu, 1997. Geometrical synthesis of the rotary cam and balance tappet mechanism. Bucharest, 3: 23-23.

Antonescu, P., F.I.T. Petrescu and O. Antonescu, 2000a. Contributions to the synthesis of the rotary disc-cam profile. Proceedings of the 8th International Conference on the Theory of Machines and Mechanisms, (TMM' 00), Liberec, Czech Republic, pp: 51-56.

Antonescu, P., F.I.T. Petrescu and O. Antonescu, $2000 \mathrm{~b}$. Synthesis of the rotary cam profile with balance follower. Proceedings of the 8th Symposium on Mechanisms and Mechanical Transmissions, (MMT'00), Timişoara, pp: 39-44.

Antonescu, P., F. Petrescu and O. Antonescu, 2001. Contributions to the synthesis of mechanisms with rotary disc-cam. Proceedings of the 8th IFToMM International Symposium on Theory of Machines and Mechanisms, (TMM' 01), Bucharest, ROMANIA, pp: 31-36.

Ascione, F., N. Bianco, R.F. De Masi, F. de Rossi and C. De Stasio et al., 2016. Energy audit of health care facilities: dynamic simulation of energy performances and energy-oriented refurbishment of system and equipment for microclimatic control. Am. J. Eng. Applied Sci., 9: 814-834.

DOI: 10.3844/ajeassp.2016.814.834

Augustine, A., R.D. Prakash, R. Xavier and M.C. Parassery, 2016. Review of signal processing techniques for detection of power quality events. Am. J. Eng. Applied Sci., 9: 364-370. DOI: 10.3844/ajeassp.2016.364.370

Aversa, R., R.V.V. Petrescu, A. Apicella and F.I.T. Petrescu, 2017a. Nano-diamond hybrid materials for structural biomedical application. Am. J. Biochem. Biotechnol., 13: 34-41. DOI: 10.3844/ajbbsp.2017.34.41

Aversa, R., R.V. Petrescu, B. Akash, R.B. Bucinell and J.M. Corchado et al., 2017b. Kinematics and forces to a new model forging manipulator. Am. J. Applied Sci., 14: 60-80. DOI: 10.3844/ajassp.2017.60.80

Aversa, R., R.V. Petrescu, A. Apicella, F.I.T. Petrescu and J.K. Calautit et al., 2017c. Something about the $\mathrm{V}$ engines design. Am. J. Applied Sci., 14: 34-52. DOI: 10.3844/ajassp.2017.34.52

Aversa, R., D. Parcesepe, R.V.V. Petrescu, F. Berto and G. Chen et al., 2017d. Process ability of bulk metallic glasses. Am. J. Applied Sci., 14: 294-301. DOI: 10.3844/ajassp.2017.294.301
Aversa, R., R.V.V. Petrescu, B. Akash, R.B. Bucinell and J.M. Corchado et al., 2017e. Something about the balancing of thermal motors. Am. J. Eng. Applied Sci., 10: 200.217. DOI: 10.3844/ajeassp.2017.200.217

Aversa, R., F.I.T. Petrescu, R.V. Petrescu and A. Apicella, 2016a. Biomimetic FEA bone modeling for customized hybrid biological prostheses development. Am. J. Applied Sci., 13: 1060-1067. DOI: 10.3844/ajassp.2016.1060.1067

Aversa, R., D. Parcesepe, R.V. Petrescu, G. Chen and F.I.T. Petrescu et al., 2016b. Glassy amorphous metal injection molded induced morphological defects. Am. J. Applied Sci., 13: 1476-1482. DOI: 10.3844/ajassp.2016.1476.1482

Aversa, R., R.V. Petrescu, F.I.T. Petrescu and A. Apicella, 2016c. Smart-factory: Optimization and process control of composite centrifuged pipes. Am. J. Applied Sci., 13: 1330-1341. DOI: 10.3844/ajassp.2016.1330.1341

Aversa, R., F. Tamburrino, R.V. Petrescu, F.I.T. Petrescu and M. Artur et al., 2016d. Biomechanically inspired shape memory effect machines driven by muscle like acting NiTi alloys. Am. J. Applied Sci., 13: 1264-1271.

DOI: 10.3844/ajassp.2016.1264.1271

Aversa, R., E.M. Buzea, R.V. Petrescu, A. Apicella and M. Neacsa et al., 2016e. Present a mechatronic system having able to determine the concentration of carotenoids. Am. J. Eng. Applied Sci., 9: 1106-1111. DOI: 10.3844/ajeassp.2016.1106.1111

Aversa, R., R.V. Petrescu, R. Sorrentino, F.I.T. Petrescu and A. Apicella, 2016f. Hybrid ceramopolymeric nanocomposite for biomimetic scaffolds design and preparation. Am. J. Eng. Applied Sci., 9: 1096-1105. DOI: 10.3844/ajeassp.2016.1096.1105

Aversa, R., V. Perrotta, R.V. Petrescu, C. Misiano and F.I.T. Petrescu et al., 2016g. From structural colors to super-hydrophobicity and achromatic transparent protective coatings: Ion plating plasma assisted $\mathrm{TiO}_{2}$ and $\mathrm{SiO}_{2}$ nano-film deposition. Am. J. Eng. Applied Sci., 9: 1037-1045.

DOI: 10.3844 /ajeassp.2016.1037.1045

Aversa, R., R.V. Petrescu, F.I.T. Petrescu and A. Apicella, 2016h. Biomimetic and evolutionary design driven innovation in sustainable products development. Am. J. Eng. Applied Sci., 9: 10271036. DOI: 10.3844 /ajeassp.2016.1027.1036

Aversa, R., R.V. Petrescu, A. Apicella and F.I.T. Petrescu, 2016i. Mitochondria are naturally micro robots - a review. Am. J. Eng. Applied Sci., 9: 991-1002. DOI: 10.3844/ajeassp.2016.991.1002 
Aversa, R., R.V. Petrescu, A. Apicella and F.I.T. Petrescu, 2016j. We are addicted to vitamins $\mathrm{C}$ and EA review. Am. J. Eng. Applied Sci., 9: 1003-1018. DOI: 10.3844 /ajeassp.2016.1003.1018

Aversa, R., R.V. Petrescu, A. Apicella and F.I.T. Petrescu, 2016k. Physiologic human fluids and swelling behavior of hydrophilic biocompatible hybrid ceramo-polymeric materials. Am. J. Eng. Applied Sci., 9: 962-972. DOI: 10.3844 /ajeassp.2016.962.972

Aversa, R., R.V. Petrescu, A. Apicella and F.I.T. Petrescu, 2016l. One can slow down the aging through antioxidants. Am. J. Eng. Applied Sci., 9: 1112-1126. DOI: 10.3844/ajeassp.2016.1112.1126

Aversa, R., R.V. Petrescu, A. Apicella and F.I.T. Petrescu, 2016m. About homeopathy or «Similia Similibus Curentur 》. Am. J. Eng. Applied Sci., 9: 1164-1172. DOI: 10.3844/ajeassp.2016.1164.1172

Aversa, R., R.V. Petrescu, A. Apicella and F.I.T. Petrescu, 2016n. The basic elements of life's. Am. J. Eng. Applied Sci., 9: 1189-1197. DOI: 10.3844/ajeassp.2016.1189.1197

Aversa, R., F.I.T. Petrescu, R.V. Petrescu and A. Apicella, 2016o. Flexible stem trabecular prostheses. Am. J. Eng. Applied Sci., 9: 1213-1221. DOI: 10.3844/ajeassp.2016.1213.122

Babayemi, A.K., 2016. Thermodynamics, non-linear isotherms, statistical modeling and optimization of phosphorus adsorption from wastewater. Am. J. Eng. Applied Sci., 9: 1019-1026. DOI: 10.3844/ajeassp.2016.1019.1026

Bakar, R.A., M.K. Mohammed and M.M. Rahman, 2009. Numerical study on the performance characteristics of hydrogen fueled port injection internal combustion engine. Am. J. Eng. Applied Sci., 2: 407-415.

DOI: $10.3844 /$ ajeassp.2009.407.415

Barone, G., A. Buonomano, C. Forzano and A. Palombo, 2016. WLHP systems in commercial buildings: A case study analysis based on a dynamic simulation approach. Am. J. Eng. Applied Sci., 9: 659-668. DOI: 10.3844/ajeassp.2016.659.668

Bedon, C., 2016. Review on the use of FRP composites for facades and building skins. Am. J. Eng. Applied Sci., 9: 713-723. DOI: 10.3844 /ajeassp.2016.713.723

Bedon, C. and C. Amadio, 2016. A unified approach for the shear buckling design of structural glass walls with non-ideal restraints. Am. J. Eng. Applied Sci., 9: 64-78. DOI: 10.3844/ajeassp.2016.64.78

Bedon, C. and C. Louter, 2016. Finite-element numerical simulation of the bending performance of posttensioned structural glass beams with adhesively bonded CFRP tendons. Am. J. Eng. Applied Sci., 9: 680-691. DOI: 10.3844/ajeassp.2016.680.691
Bier, H. and S. Mostafavi, 2015. Structural optimization for materially informed design to robotic production processes. Am. J. Eng. Applied Sci., 8: 549-555. DOI: 10.3844 ajeassp.2015.549.555

Bolonkin, A., 2009a. Femtotechnology: Nuclear matter with fantastic properties. Am. J. Eng. Applied Sci., 2: 501-514.

DOI: 10.3844/ajeassp.2009.501.514

Bolonkin, A., 2009b. Converting of matter to nuclear energy by ab-generator. Am. J. Eng. Applied Sci., 2: 683-693. DOI: 10.3844/ajeassp.2009.683.693

Boucetta, A., 2008. Vector control of a variable reluctance machine stator and rotor discs imbricates. Am. J. Eng. Applied Sci., 1: 260-265. DOI: 10.3844/ajeassp.2008.260.265

Bourahla, N. and A. Blakeborough, 2015. Similitude distortion compensation for a small scale model of a knee braced steel frame. Am. J. Eng. Applied Sci., 8: 481-488. DOI: 10.3844/ajeassp.2015.481.488

Bucinell, R.B., 2016. Stochastic model for variable amplitude fatigue induced delamination growth in graphite/epoxy laminates. Am. J. Eng. Applied Sci., 9: 635-646. DOI: 10.3844/ajeassp.2016.635.646

Budak, S., Z. Xiao, B. Johnson, J. Cole and M. Drabo et al., 2016. Highly-efficient advanced thermoelectric devices from different multilayer thin films. Am. J. Eng. Applied Sci., 9: 356-363. DOI: 10.3844 /ajeassp.2016.356.363

Buonomano, A., F. Calise and M. Vicidomini, 2016a. A novel prototype of a small-scale solar power plant: Dynamic simulation and thermoeconomic analysis. Am. J. Eng. Applied Sci., 9: 770-788.

DOI: $10.3844 /$ ajeassp.2016.770.788

Buonomano, A., F. Calise, M.D. d'Accadia, R. Vanoli and M. Vicidomini, 2016b. Simulation and experimental analysis of a demonstrative solar heating and cooling plant installed in Naples (Italy). Am. J. Eng. Applied Sci., 9: 798-813. DOI: 10.3844/ajeassp.2016.798.813

Cao, W., H. Ding, Z. Bin and C. Ziming, 2013. New structural representation and digital-analysis platform for symmetrical parallel mechanisms. Int. J. Adv. Robotic Sys. DOI: 10.5772/56380

Calise, F., M.D. dâ' Accadia, L. Libertini, E. Quiriti and M. Vicidomini, 2016b. Dynamic simulation and optimum operation strategy of a trigeneration system serving a hospital. Am. J. Eng. Applied Sci., 9: 854-867. DOI: 10.3844/ajeassp.2016.854.867

Campo, T., M. Cotto, F. Marquez, E. Elizalde and C. Morant, 2016. Graphene synthesis by plasmaenhanced CVD growth with ethanol. Am. J. Eng. Applied Sci., 9: 574-583. DOI: 10.3844/ajeassp.2016.574.583 
Cardu, M., P. Oreste and T. Cicala, 2009. Analysis of the tunnel boring machine advancement on the Bologna-Florence railway link. Am. J. Eng. Applied Sci., 2: 416-420.

DOI: $10.3844 /$ ajeassp.2009.416.420

Casadei, D., 2015. Bayesian statistical inference for number counting experiments. Am. J. Eng. Applied Sci., 8: 730-735.

DOI: 10.3844 /ajeassp.2015.730.735

Cataldo, R., 2006. Overview of planetary power system options for education. ITEA Human Exploration Project Authors, Glenn Research Center. Brooke Park, OH.

Chang, S.P., M.C. Chen and J.D. Lin, 2015. Study of heat-treated steel and related applications. Am. J. Eng. Applied Sci., 8: 611-619.

DOI: 10.3844/ajeassp.2015.611.619

Chen, G. and L. Xu, 2016. A general strategy to enhance up conversion luminescence in rare-earth-iondoped oxide nanocrystals. Am. J. Eng. Applied Sci., 9: 79-83. DOI: 10.3844/ajeassp.2016.79.83

Chiozzi, A., G. Milani, N. Grillanda and A. Tralli, 2016. An adaptive procedure for the limit analysis of FRP reinforced masonry vaults and applications. Am. J. Eng. Applied Sci., 9: 735-745. DOI: 10.3844 /ajeassp.2016.735.745

Chisari, C. and C. Bedon, 2016. Multi-objective optimization of FRP jackets for improving the seismic response of reinforced concrete frames. Am. J. Eng. Applied Sci., 9: 669-679.

DOI: 10.3844 /ajeassp.2016.669.679

Comanescu, A., 2010. Bazele Modelarii Mecanismelor. 1st Edn., E. Politeh, Press, București, pp: 274.

Darabi, A., S.A. Soleamani and A. Hassannia, 2008. Fuzzy based digital automatic voltage regulator of a synchronous generator with unbalanced loads. Am. J. Eng. Applied Sci., 1: 280-286. DOI: 10.3844 /ajeassp.2008.280.286

Daud, H., N. Yahya, A.A. Aziz and M.F. Jusoh, 2008. Development of wireless electric concept powering electrical appliances. Am. J. Eng. Applied Sci., 1: 12-15. DOI: 10.3844/ajeassp.2008.12.15

Demetriou, D., N. Nikitas and K.D. Tsavdaridis, 2015. Semi active tuned mass dampers of buildings: A simple control option. Am. J. Eng. Applied Sci., 8: 620-632. DOI: 10.3844/ajeassp.2015.620.632

Dixit, S. and S. Pal, 2015. Synthesis and characterization of ink (Carbon)-perovskite/polyaniline ternary composite electrode for sodium chloride separation. Am. J. Eng. Applied Sci., 8: 527-537. DOI: 10.3844 /ajeassp.2015.527.537

Djalel, D., M. Mourad and H. Labar, 2013. New approach of electromagnetic fields of the lightning discharge. Am. J. Eng. Applied Sci., 6: 369-383. DOI: 10.3844/ajeassp.2013.369.383
Dong, H., N. Giakoumidis, N. Figueroa and N. Mavridis, 2013. Approaching behaviour monitor and vibration indication in developing a General Moving Object Alarm System (GMOAS). Int. J. Adv. Robotic Sys. DOI: $10.5772 / 56586$

Ebrahim, N.A., S. Ahmed, S.H.A. Rashid and Z. Taha, 2012. Technology use in the virtual R\&D teams. Am. J. Eng. Applied Sci., 5: 9-14. DOI: 10.3844/ajeassp.2012.9.14

El-Labban, H.F., M. Abdelaziz and E.R.I. Mahmoud, 2013. Modification of carbon steel by laser surface melting: Part I: Effect of laser beam travelling speed on microstructural features and surface hardness. Am. J. Eng. Applied Sci., 6: 352-359. DOI: 10.3844/ajeassp.2013.352.359

Elliott, A., S. AlSalihi, A.L. Merriman and M.M. Basti, 2016. Infiltration of nanoparticles into porous binder jet printed parts. Am. J. Eng. Applied Sci., 9: 128-133. DOI: 10.3844/ajeassp.2016.128.133

Elmeddahi, Y., H. Mahmoudi, A. Issaadi, M.F.A. Goosen and R. Ragab, 2016b. Evaluating the effects of climate change and variability on water resources: A case study of the cheliff Basin in Algeria. Am. J. Eng. Applied Sci., 9: 835-845. DOI: 10.3844 /ajeassp.2016.835.845

El-Tous, Y., 2008. Pitch angle control of variable speed wind turbine. Am. J. Eng. Applied Sci., 1: 118-120. DOI: 10.3844/ajeassp.2008.118.120

Faizal, A., S. Mulyono, R. Yendra and A. Fudholi, 2016. Design Maximum Power Point Tracking (MPPT) on photovoltaic panels using fuzzy logic method. Am. J. Eng. Applied Sci., 9: 789-797. DOI: 10.3844/ajeassp.2016.789.797

Farahani, A.S., N.M. Adam and M.K.A. Ariffin, 2010. Simulation of airflow and aerodynamic forces acting on a rotating turbine ventilator. Am. J. Eng. Applied Sci., 3: 159-170. DOI: 10.3844 /ajeassp.2010.159.170

Farokhi, E. and M. Gordini, 2015. Investigating the parameters influencing the behavior of knee braced steel structures. Am. J. Eng. Applied Sci., 8: 567-574. DOI: 10.3844/ajeassp.2015.567.574

Fathallah, A.Z.M. and R.A. Bakar, 2009. Prediction studies for the performance of a single cylinder high speed spark ignition linier engine with spring mechanism as return cycle. Am. J. Eng. Applied Sci., 2: 713-720.

DOI: 10.3844 ajeassp.2009.713.720

Fawcett, G.F. and J.N. Fawcett, 1974. Comparison of Polydyne and Non Polydyne Cams. In: Cams and Cam Mechanisms, Rees Jones, J. (Ed.), MEP, London and Birmingham, Alabama. 
Fen, Y.W., W.M.M. Yunus, M.M. Moksin, Z.A. Talib and N.A. Yusof, 2011. Optical properties of crosslinked chitosan thin film with glutaraldehyde using surface plasmon resonance technique. Am. J. Eng. Applied Sci., 4: 61-65. DOI: 10.3844 /ajeassp.2011.61.65

Feraga, C.E., A. Moussaoui, A. Bouldjedri and A. Yousfi, 2009. Robust position controller for a permanent magnet synchronous actuator. Am. J. Eng. Applied Sci., 2: 388-392.

DOI: 10.3844/ajeassp.2009.388.392

Franklin, D.J., 1930. Ingenious Mechanisms for Designers and Inventors. 1st Edn., Industrial Press Publisher.

Fu, Y.F., J. Gong, H. Huang, Y.J. Liu and D. Zhu et al., 2015. Parameters optimization of adaptive cashew shelling cutter based on BP neural network and genetic algorithm. Am. J. Eng. Applied Sci., 8: 648658. DOI: 10.3844/ajeassp.2015.648.658

Ge, L. and X. Xu, 2015. A scheme design of cloud + end technology in demand side management. Am. J. Eng. Applied Sci., 8: 736-747. DOI: 10.3844/ajeassp.2015.736.747

Giordana, F., V. Rognoni and G. Ruggieri, 1979. On the influence of measurement errors in the Kinematic analysis of cam. Mechanism Mach. Theory, 14: 327-340. DOI: 10.1016/0094-114X(79)90019-3

Gruener, J.E., 2006. Lunar exploration (Presentation to ITEA Human Exploration Project Authors, November 2006, at Johnson Space Center). Houston, TX.

Gupta, P., A. Gupta and A. Asati, 2015. Ultra low power MUX based compressors for wallace and dadda multipliers in sub-threshold regime. Am. J. Eng. Applied Sci., 8: 702-716. DOI: 10.3844 /ajeassp.2015.702.716

Gusti, A.P. and Semin, 2016. The effect of vessel speed on fuel consumption and exhaust gas emissions. Am. J. Eng. Applied Sci., 9: 1046-1053. DOI: 10.3844 /ajeassp.2016.1046.1053

Hain, K., 1971. Optimization of a cam mechanism to give good transmissibility maximal output angle of swing and minimal acceleration. J. Mechanisms, 6: 419-434. DOI: 10.1016/0022-2569(71)90044-9

Hassan, M., H. Mahjoub and M. Obed, 2012. Voicebased control of a DC servo motor. Am. J. Eng. Applied Sci., 5: 89-92. DOI: 10.3844 /ajeassp.2012.89.92

Hasan, S. and M.H. El-Naas, 2016. Optimization of a combined approach for the treatment of carbide slurry and capture of $\mathrm{CO}_{2}$. Am. J. Eng. Applied Sci., 9: 449-457. DOI: 10.3844/ajeassp.2016.449.457

Helmy, A.K. and G.S. El-Taweel, 2010. Neural network change detection model for satellite images using textural and spectral characteristics. Am. J. Eng. Applied Sci., 3: 604-610.

DOI: $10.3844 /$ ajeassp.2010.604.610
Hirun, W., 2016. Evaluation of interregional freight generation modelling methods by using nationwide commodity flow survey data. Am. J. Eng. Applied Sci., 9: 625-634.

DOI: 10.3844 ajeassp.2016.625.634

Ho, C.Y.F., B.W.K. Ling, S.G. Blasi, Z.W. Chi and W.C. Siu, 2011. Single step optimal block matched motion estimation with motion vectors having arbitrary pixel precisions. Am. J. Eng. Applied Sci., 4: 448-460. DOI: 10.3844/ajeassp.2011.448.460

Huang, B., S.H. Masood, M. Nikzad, P.R. Venugopal and A. Arivazhagan, 2016. Dynamic mechanical properties of fused deposition modelling processed polyphenylsulfone material. Am. J. Eng. Applied Sci., 9: 1-11. DOI: 10.3844/ajeassp.2016.1.11

He, B., Z. Wang, Q. Li, H. Xie and R. Shen, 2013. An analytic method for the kinematics and dynamics of a multiple-backbone continuum robot. IJARS. DOI: $10.5772 / 54051$

Idarwazeh, S., 2011. Inverse discrete Fourier transformdiscrete Fourier transform techniques for generating and receiving spectrally efficient frequency division multiplexing signals. Am. J. Eng. Applied Sci., 4: 598-606. DOI: 10.3844/ajeassp.2011.598.606

Iqbal, 2016. An overview of Energy Loss Reduction (ELR) software used in Pakistan by WAPDA for calculating transformer overloading, line losses and energy losses. Am. J. Eng. Applied Sci., 9: 442-448. DOI: 10.3844/ajeassp.2016.442.448

Ismail, M.I.S., Y. Okamoto, A. Okada and Y. Uno, 2011. Experimental investigation on micro-welding of thin stainless steel sheet by fiber laser. Am. J. Eng. Applied Sci., 4: 314-320. DOI: 10.3844/ajeassp.2011.314.320

Jaber, A.A. and R. Bicker, 2016. Industrial robot fault detection based on statistical control chart. Am. J. Eng. Applied Sci., 9: 251-263. DOI: 10.3844 /ajeassp.2016.251.263

Jafari, N., A. Alsadoon, C.P. Withana, A. Beg and A. Elchouemi, 2016. Designing a comprehensive security framework for smartphones and mobile devices. Am. J. Eng. Applied Sci., 9: 724-734. DOI: 10.3844/ajeassp.2016.724.734

Jalil, M.I.A. and J. Sampe, 2013. Experimental investigation of thermoelectric generator modules with different technique of cooling system. Am. J. Eng. Applied Sci., 6: 1-7. DOI: 10.3844/ajeassp.2013.1.7

Jaoude, A.A. and K. El-Tawil, 2013. Analytic and nonlinear prognostic for vehicle suspension systems. Am. J. Eng. Applied Sci., 6: 42-56. DOI: 10.3844 /ajeassp.2013.42.56

Jarahi, H., 2016. Probabilistic seismic hazard deaggregation for Karaj City (Iran). Am. J. Eng. Applied Sci., 9: 520-529.

DOI: 10.3844/ajeassp.2016.520.529 
Jarahi, H. and S. Seifilaleh, 2016. Rock fall hazard zonation in Haraz Highway. Am. J. Eng. Applied Sci., 9: 371-379.

DOI: 10.3844 /ajeassp.2016.371.379

Jauhari, K., A. Widodo and I. Haryanto, 2016. Identification of a machine tool spindle critical frequency through modal and imbalance response analysis. Am. J. Eng. Applied Sci., 9: 213-221.

DOI: 10.3844/ajeassp.2016.213.221

Jiang, J., Q. Chen and S. Nimbalkar, 2016. Field data based method for predicting long-term settlements. Am. J. Eng. Applied Sci., 9: 466-476.

DOI: 10.3844/ajeassp.2016.466.476

Jones, J.R. and J.E. Reeve, 1974. Dynamic Response of Cam Curves Based on Sinusoidal Segments. In: Cams and cam Mechanisms, Rees Jones, J. (Ed.), MEP, London and Birmingham, Alabama.

Kaewnai, S. and S. Wongwises, 2011. Improvement of the runner design of francis turbine using computational fluid dynamics. Am. J. Eng. Applied Sci., 4: 540-547.

DOI: $10.3844 /$ ajeassp.2011.540.547

Khalifa, A.H.N., A.H. Jabbar and J.A. Muhsin, 2015. Effect of exhaust gas temperature on the performance of automobile adsorption airconditioner. Am. J. Eng. Applied Sci., 8: 575-581. DOI: 10.3844/ajeassp.2015.575.581

Khalil, R., 2015. Credibility of 3D volume computation using GIS for pit excavation and roadway constructions. Am. J. Eng. Applied Sci., 8: 434-442. DOI: 10.3844/ajeassp.2015.434.442

Kamble, V.G. and N. Kumar, 2016. Fabrication and tensile property analysis of polymer matrix composites of graphite and silicon carbide as fillers. Am. J. Eng. Applied Sci., 9: 17-30. DOI: 10.3844 /ajeassp.2016.17.30

Kazakov, V.V., V.I. Yusupov, V.N. Bagratashvili, A.I. Pavlikov and V.A. Kamensky, 2016. Control of bubble formation at the optical fiber tip by analyzing ultrasound acoustic waves. Am. J. Eng. Applied Sci., 9: 921-927.

DOI: 10.3844/ajeassp.2016.921.927

Kechiche, O.B.H.B., H.B.A. Sethom, H. Sammoud and I.S. Belkhodja, 2011. Optimized highfrequency signal injection based permanent magnet synchronous motor rotor position estimation applied to washing machines. Am. J. Eng. Applied Sci., 4: 390-399. DOI: 10.3844/ajeassp.2011.390.399

Koster, M.P., 1974. The Effects of Backlash and Shaft Flexibility on the Dynamic Behavior of a Cam Mechanism. In: Cams and Cam Mechanisms, Rees Jones, J. (Ed.), MEP, London and Birmingham, Alabama.
Kuli, I., T.M. Abu-Lebdeh, E.H. Fini and S.A. Hamoush, 2016. The use of nano-silica for improving mechanical properties of hardened cement paste. Am. J. Eng. Applied Sci., 9: 146-154. DOI: 10.3844 /ajeassp.2016.146.154

Kumar, N.D., R.D. Ravali and PR. Srirekha, 2015. Design and realization of pre-amplifier and filters for on-board radar system. Am. J. Eng. Applied Sci., 8: 689-701. DOI: 10.3844/ajeassp.2015.689.701

Kunanoppadon, J., 2010. Thermal efficiency of a combined turbocharger set with gasoline engine. Am. J. Eng. Applied Sci., 3: 342-349. DOI: 10.3844 /ajeassp.2010.342.349

Kwon, S., Y. Tani, H. Okubo and T. Shimomura, 2010. Fixed-star tracking attitude control of spacecraft using single-gimbal control moment gyros. Am. J. Eng. Applied Sci., 3: 49-55. DOI: 10.3844 /ajeassp.2010.49.55

Lamarre, A., E.H. Fini and T.M. Abu-Lebdeh, 2016. Investigating effects of water conditioning on the adhesion properties of crack sealant. Am. J. Eng. Applied Sci., 9: 178-186.

DOI: 10.3844/ajeassp.2016.178.186

Lee, B.J., 2013. Geometrical derivation of differential kinematics to calibrate model parameters of flexible manipulator. Int. J. Adv. Robotic Sys. DOI: $10.5772 / 55592$

Li, R., B. Zhang, S. Xiu, H. Wang and L. Wang et al., 2015. Characterization of solid residues obtained from supercritical ethanol liquefaction of swine manure. Am. J. Eng. Applied Sci., 8: 465- 470. DOI: 10.3844/ajeassp.2015.465.470

Lin, W., B. Li, X. Yang and D. Zhang, 2013. Modelling and control of inverse dynamics for a 5-DOF parallel kinematic polishing machine. Int. J. Adv. Robotic Sys. DOI: 10.5772/54966

Liu, H., W. Zhou, X. Lai and S. Zhu, 2013. An efficient inverse kinematic algorithm for a PUMA560structured robot manipulator. IJARS. DOI: $10.5772 / 56403$

Lubis, Z., A.N. Abdalla, Mortaza and R. Ghon, 2009. Mathematical modeling of the three phase induction motor couple to DC motor in hybrid electric vehicle. Am. J. Eng. Applied Sci., 2: 708-712. DOI: 10.3844/ajeassp.2009.708.712

Madani, D.A. and A. Dababneh, 2016. Rapid entire body assessment: A literature review. Am. J. Eng. Applied Sci., 9: 107-118. DOI: 10.3844 ajeassp.2016.107.118

Malomar, G.E.B., A. Gueye, C. Mbow, V.B. Traore and A.C. Beye, 2016. Numerical study of natural convection in a square porous cavity thermally modulated on both side walls. Am. J. Eng. Applied Sci., 9: 591-598.

DOI: 10.3844/ajeassp.2016.591.598 
Mansour, M.A.A., 2016. Developing an anthropometric database for Saudi students and comparing Saudi dimensions relative to Turkish and Iranian peoples. Am. J. Eng. Applied Sci., 9: 547-557. DOI: 10.3844/ajeassp.2016.547.557

Maraveas, C., Z.C. Fasoulakis and K.D. Tsavdaridis, 2015. A review of human induced vibrations on footbridges. Am. J. Eng. Applied Sci., 8: 422-433. DOI: 10.3844 /ajeassp.2015.422.433

Marghany, M. and M. Hashim, 2009. Robust of doppler centroid for mapping sea surface current by using radar satellite data. Am. J. Eng. Applied Sci., 2: 781-788.

DOI: 10.3844/ajeassp.2009.781.788

Martins, F.R., A.R. Gonçalves and E.B. Pereira, 2016. Observational study of wind shear in northeastern Brazil. Am. J. Eng. Applied Sci., 9: 484-504. DOI: 10.3844/ajeassp.2016.484.504

Marzuki, M.A.L.B., M.H. Abd Halim and A.R.N. Mohamed, 2015. Determination of natural frequencies through modal and harmonic analysis of space frame race car chassis based on ANSYS. Am. J. Eng. Applied Sci., 8: 538-548.

DOI: 10.3844/ajeassp.2015.538.548

Mavukkandy, M.O., S. Chakraborty, T. Abbasi and S.A. Abbasi, 2016. A clean-green synthesis of platinum nanoparticles utilizing a pernicious weed lantana (Lantana Camara). Am. J. Eng. Applied Sci., 9: 84-90.

DOI: 10.3844 /ajeassp.2016.84.90

Minghini, F., N. Tullini and F. Ascione, 2016. Updating Italian design guide CNR DT-205/2007 in view of recent research findings: Requirements for pultruded FRP profiles. Am. J. Eng. Applied Sci., 9: 702-712. DOI: 10.3844/ajeassp.2016.702.712

Moezi, N., D. Dideban and A. Ketabi, 2008. A novel integrated SET based inverter for nano power electronic applications. Am. J. Eng. Applied Sci., 1: 219-222. DOI: 10.3844/ajeassp.2008.219.222

Mohamed, M.A., A.Y. Tuama, M. Makhtar, M.K. Awang and M. Mamat, 2016. The effect of RSA exponential key growth on the multi-core computational resource. Am. J. Eng. Applied Sci., 9: 1054-1061.

DOI: 10.3844/ajeassp.2016.1054.1061

Mohan, K.S.R., P. Jayabalan and A. Rajaraman, 2012. Properties of fly ash based coconut fiber composite. Am. J. Eng. Applied Sci., 5: 29-34.

DOI: 10.3844/ajeassp.2012.29.34

Mohseni, E. and K.D. Tsavdaridis, 2016. Effect of nanoalumina on pore structure and durability of class $f$ fly ash self-compacting mortar. Am. J. Eng. Applied Sci., 9: 323-333.

DOI: 10.3844 /ajeassp.2016.323.333
Momani, M.A., T.A. Al Smadi, FM. Al Taweel and K.A. Ghaidan, 2011. GPS ionospheric total electron content and scintillation measurements during the October 2003 magnetic storm. Am. J. Eng. Applied Sci., 4: 301-306. DOI: 10.3844 /ajeassp.2011.301.306

Momta, P.S., J.O. Omoboh and M.I. Odigi, 2015. Sedimentology and depositional environment of D2 sand in part of greater ughelli depobelt, onshore Niger Delta, Nigeria. Am. J. Eng. Applied Sci., 8: 556-566. DOI: 10.3844/ajeassp.2015.556.566

Mondal, R., S. Sahoo and C.S. Rout, 2016. Mixed nickel cobalt manganese oxide nanorods for supercapacitor application. Am. J. Eng. Applied Sci., 9: 540-546. DOI: 10.3844 /ajeassp.2016.540.546

Montgomery, J., T.M. Abu-Lebdeh, S.A. Hamoush and M. Picornell, 2016. Effect of nano-silica on the compressive strength of harden cement paste at different stages of hydration. Am. J. Eng. Applied Sci., 9: 166-177.

DOI: 10.3844/ajeassp.2016.166.177

Moretti, M.L., 2015. Seismic design of masonry and reinforced concrete infilled frames: A comprehensive overview. Am. J. Eng. Applied Sci., 8: 748-766. DOI: 10.3844/ajeassp.2015.748.766

Morse, A., M.M. Mansfield, R.M. Alley, H.A. Kerr and R.B. Bucinell, 2016b. Traction enhancing products affect maximum torque at the shoe-floor interface: A potential increased risk of ACL injury. Am. J. Eng. Applied Sci., 9: 889-893.

DOI: 10.3844/ajeassp.2016.889.893

Moubarek, T. and A. Gharsallah, 2016. A six-port reflectometer calibration using Wilkinson power divider. Am. J. Eng. Applied Sci., 9: 274-280. DOI: 10.3844 /ajeassp.2016.274.280

Nabilou, A., 2016a. Effect of parameters of selection and replacement drilling bits based on geo-mechanical factors: (Case study: Gas and oil reservoir in the Southwest of Iran). Am. J. Eng. Applied Sci., 9: 380-395. DOI: 10.3844/ajeassp.2016.380.395

Nabilou, A., 2016b. Study of the parameters of Steam Assisted Gravity Drainage (SAGD) method for enhanced oil recovery in a heavy oil fractured carbonate reservoir. Am. J. Eng. Applied Sci., 9: 647-658. DOI: 10.3844/ajeassp.2016.647.658

Nachiengtai, T., W. Chim-Oye, S. Teachavorasinskun and W. Sa-Ngiamvibool, 2008. Identification of shear band using elastic shear wave propagation. Am. J. Eng. Applied Sci., 1: 188-191.

DOI: 10.3844 /ajeassp.2008.188.191

Nahas, R. and S.P. Kozaitis, 2014. Metric for the fusion of synthetic and real imagery from multimodal sensors. Am. J. Eng. Applied Sci., 7: 355-362. DOI: 10.3844 /ajeassp.2014.355.362 
Nandhakumar, S., V. Selladurai and S. Sekar, 2009. Numerical investigation of an industrial robot arm control problem using haar wavelet series. Am. J. Eng. Applied Sci., 2: 584-589.

DOI: 10.3844/ajeassp.2009.584.589

Ng, K.C., M.Z. Yusoff, K. Munisamy, H. Hasini and N.H. Shuaib, 2008. Time-marching method for computations of high-speed compressible flow on structured and unstructured grid. Am. J. Eng. Applied Sci., 1: 89-94.

DOI: 10.3844/ajeassp.2008.89.94

Obaiys, S.J., Z. Abbas, N.M.A. Nik Long, A.F. Ahmad and A. Ahmedov et al., 2016. On the general solution of first-kind hypersingular integral equations. Am. J. Eng. Applied Sci., 9: 195-201. DOI: 10.3844/ajeassp.2016.195.201

Odeh, S., R. Faqeh, L. Abu Eid and N. Shamasneh, 2009. Vision-based obstacle avoidance of mobile robot using quantized spatial model. Am. J. Eng. Applied Sci., 2: 611-619. DOI: 10.3844/ajeassp.2009.611.619

Ong, A.T., A. Mustapha, Z.B. Ibrahim, S. Ramli and B.C. Eong, 2015. Real-time automatic inspection system for the classification of PCB flux defects. Am. J. Eng. Applied Sci., 8: 504-518. DOI: 10.3844/ajeassp.2015.504.518

Opafunso, Z.O., I.I. Ozigis and I.A. Adetunde, 2009. Pneumatic and hydraulic systems in coal fluidized bed combustor. Am. J. Eng. Applied Sci., 2: 88-95. DOI: 10.3844/ajeassp.2009.88.95

Orlando, N. and E. Benvenuti, 2016. Advanced XFEM simulation of pull-out and debonding of steel bars and FRP-reinforcements in concrete beams. Am. J. Eng. Applied Sci., 9: 746-754. DOI: 10.3844/ajeassp.2016.746.754

Pannirselvam, N., P.N. Raghunath and K. Suguna, 2008. Neural network for performance of glass fibre reinforced polymer plated RC beams. Am. J. Eng. Applied Sci., 1: 82-88.

DOI: 10.3844/ajeassp.2008.82.88

Pattanasethanon, S., 2010. The solar tracking system by using digital solar position sensor. Am. J. Eng. Applied Sci., 3: 678-682. DOI: 10.3844 /ajeassp.2010.678.682

Pérez-de León, G., V.E. Lamberti, R.D. Seals, T.M. Abu-Lebdeh and S.A. Hamoush, 2016. Gas atomization of molten metal: Part I. Numerical modeling conception. Am. J. Eng. Applied Sci., 9: 303-322. DOI: 10.3844/ajeassp.2016.303.322

Padula, F. and V. Perdereau, 2013. An on-line path planner for industrial manipulators. Int. J. Adv. Robotic Sys. DOI: 10.5772/55063

Perumaal, S. and N. Jawahar, 2013. Automated trajectory planner of industrial robot for pick-andplace task. IJARS. DOI: 10.5772/53940
Petrescu, F. and R. Petrescu, 1995a. Contributions to optimization of the polynomial motion laws of the stick from the internal combustion engine distribution mechanism. Bucharest, 1: 249-256.

Petrescu, F. and R. Petrescu, 1995b. Contributions to the synthesis of internal combustion engine distribution mechanisms. Bucharest, 1: 257-264.

Petrescu, F. and R. Petrescu, 1997a. Dynamics of cam mechanisms (exemplified on the classic distribution mechanism). Bucharest, 3: 353-358.

Petrescu, F. and R. Petrescu, 1997b. Contributions to the synthesis of the distribution mechanisms of internal combustion engines with a Cartesian coordinate method. Bucharest, 3: 359-364.

Petrescu, F. and R. Petrescu, 1997c. Contributions to maximizing polynomial laws for the active stroke of the distribution mechanism from internal combustion engines. Bucharest, 3: 365-370.

Petrescu, F. and R. Petrescu, 2000a. Synthesis of distribution mechanisms by the rectangular (Cartesian) coordinate method. Proceedings of the 8th National Conference on International Participation, (CIP' 00), Craiova, Romania, pp: 297-302.

Petrescu, F. and R. Petrescu, 2000b. The design (synthesis) of cams using the polar coordinate method (triangle method). Proceedings of the 8th National Conference on International Participation, (CIP' 00), Craiova, Romania, pp: 291-296.

Petrescu, F. and R. Petrescu, 2002a. Motion laws for cams. Proceedings of the International Computer Assisted Design, National Symposium with Participation, (SNP' 02), Braşov, pp: 321-326.

Petrescu, F. and R. Petrescu, 2002b. Camshaft dynamics elements. Proceedings of the International Computer Assisted Design, National Participation Symposium, (SNP' 02), Braşov, pp: 327-332.

Petrescu, F. and R. Petrescu, 2003. Some elements regarding the improvement of the engine design. Proceedings of the National Symposium, Descriptive Geometry, Technical Graphics and Design, (GTD' 03), Braşov, pp: 353-358.

Petrescu, F. and R. Petrescu, 2005a. The cam design for a better efficiency. Proceedings of the International Conference on Engineering Graphics and Design, (EGD' 05), Bucharest, pp: 245-248.

Petrescu, F. and R. Petrescu, 2005b. Contributions at the dynamics of cams. Proceedings of the 9th IFToMM International Symposium on Theory of Machines and Mechanisms, (TMM' 05), Bucharest, Romania, pp: 123-128.

Petrescu, F. and R. Petrescu, 2005c. Determining the dynamic efficiency of cams. Proceedings of the 9th IFToMM International Symposium on Theory of Machines and Mechanisms, (TMM' 05), Bucharest, Romania, pp: 129-134. 
Petrescu, F. and R. Petrescu, 2005d. An original internal combustion engine. Proceedings of the 9th IFToMM International Symposium on Theory of Machines and Mechanisms, (TMM' 05), Bucharest, Romania, pp: $135-140$.

Petrescu, F. and R. Petrescu, 2005e. Determining the mechanical efficiency of Otto engine's mechanism. Proceedings of the 9th IFToMM International Symposium on Theory of Machines and Mechanisms, (TMM 05), Bucharest, Romania, pp: 141-146.

Petrescu, F.I. and R.V. Petrescu, 2011a. Mechanical Systems, Serial and Parallel (Romanian). 1st Edn., LULU Publisher, London, UK, pp: 124.

Petrescu, FIT., Petrescu, RV., 2011 b. Trenuri Planetare. 1st Edn., Createspace Independent Pub., ISBN-13: 978-1468030419, pp: 104.

Petrescu, F.I. and R.V. Petrescu, 2012a. Kinematics of the planar quadrilateral mechanism. ENGEVISTA, 14: 345-348.

Petrescu, F.I. and R.V. Petrescu, 2012b. MecatronicaSisteme Seriale si Paralele. 1st Edn., Create Space Publisher, USA, pp: 128.

Petrescu, F.I. and R.V. Petrescu, 2013a. Cinematics of the 3R dyad. ENGEVISTA, 15: 118-124.

Petrescu, F.I.T. and R.V. Petrescu, 2013b. Forces and efficiency of cams. Int. Rev. Mech. Eng., 7: 507-511

Petrescu, F.I.T. and R.V. Petrescu, 2013c. Cams with high efficiency. Int. Rev. Mech. Eng., 7: 599-606

Petrescu, F.I.T. and R.V. Petrescu, 2013d. An algorithm for setting the dynamic parameters of the classic distribution mechanism. Int. Rev. Modell. Simulat., 6: 1637-1641.

Petrescu, F.I.T. and R.V. Petrescu, 2013e. Dynamic synthesis of the rotary cam and translated tappet with roll. Int. Rev. Modell. Simulat., 6: 600-607.

Petrescu, F.I.T. and R.V. Petrescu, 2014a. Parallel moving mechanical systems. Independent $\mathrm{J}$. Manage. Product., 5: 564-580.

Petrescu, F.I.T. and R.V. Petrescu, 2014b. Cam gears dynamics in the classic distribution. Independent $\mathrm{J}$. Manage. Product., 5: 166-185.

Petrescu, F.I.T. and R.V. Petrescu, 2014c. Highefficiency gears synthesis by avoid the interferences. Independent J. Manage. Product., 5: 275-298.

Petrescu, F.I.T. and R.V. Petrescu, 2014d. Gear design. J. ENGEVISTA, 16: 313-328.

Petrescu, F.I.T. and R.V. Petrescu, 2014e. Kinetostatic of the $3 \mathrm{R}$ dyad (or $2 \mathrm{R}$ module). J. ENGEVISTA, 16: 314-321.

Petrescu, F.I.T. and R.V. Petrescu, 2014f. Balancing Otto engines. Int. Rev. Mech. Eng., 8: 473-480.

Petrescu, F.I.T. and R.V. Petrescu, 2014g. Machine equations to the classical distribution. Int. Rev. Mech. Eng., 8: 309-316.
Petrescu, F.I.T. and R.V. Petrescu, 2014h. Forces of internal combustion heat engines. Int. Rev. Modell. Simulat., 7: 206-212.

Petrescu, F.I.T. and R.V. Petrescu, 2014i. Determination of the yield of internal combustion thermal engines. Int. Rev. Mech. Eng., 8: 62-67.

Petrescu, F.I.T. and R.V. Petrescu, 2015a. Forces at the main mechanism of a railbound forging manipulator. Independent J. Manage. Product., 6: 904-921.

Petrescu, F.I.T. and R.V. Petrescu, 2015b. Kinematics at the main mechanism of a railbound forging manipulator. Independent J. Manage. Product., 6: 711-729.

Petrescu, F.I.T. and R.V. Petrescu, 2015c. Machine motion equations. Independent J. Manage. Product., 6: 773-802.

Petrescu F.I.T. and R.V. Petrescu, 2015d. Presenting a railbound forging manipulator. Applied Mech. Mater., 762: 219-224.

Petrescu, F.I.T. and R.V. Petrescu, 2015e. About the anthropomorphic robots. J. ENGEVISTA, 17: 1-15.

Petrescu, F.I. and R.V. Petrescu, 2016a. Parallel moving mechanical systems kinematics. ENGEVISTA, 18: 455-491.

Petrescu, F.I. and R.V. Petrescu, 2016b. Direct and inverse kinematics to the anthropomorphic robots. ENGEVISTA, 18: 109-124.

Petrescu, F.I. and R.V. Petrescu, 2016c. Dynamic cinematic to a structure 2R. Revista Geintec-Gestao Inovacao E Tecnol., 6: 3143-3154.

Petrescu, FIT. and R.V. Petrescu, 2016d. An Otto engine dynamic model. Independent J. Manage. Product., 7: 038-048

Petrescu, R.V., R. Aversa, A. Apicella and F.I. Petrescu, 2016. Future medicine services robotics. Am. J. Eng. Applied Sci., 9: 1062-1087.

DOI: 10.3844/ajeassp.2016.1062.1087

Petrescu, F.I., B. Grecu, A. Comanescu and R.V. Petrescu, 2009. Some mechanical design elements. Proceeding of the International Conference on Computational Mechanics and Virtual Engineering, (MVE' 09), Braşov, pp: 520-525.

Petrescu, F.I.T., 2008. Ph.D. Thesis, „Theoretical and Applied Contributions About the Dynamic of Planar Mechanisms with Superior Linkages". Bucharest Polytechnic University.

Petrescu, F.I.T., 2011. Teoria Mecanismelor si a Masinilor: Curs Si Aplicatii. 1st Edn., CreateSpace Independent Publishing Platform. ISBN-10: 1468015826. pp: 432.

Petrescu, F.I.T., 2015a. Geometrical synthesis of the distribution mechanisms. Am. J. Eng. Applied Sci., 8: 63-81. DOI: 10.3844/ajeassp.2015.63.81 
Petrescu, F.I.T., 2015b. Machine motion equations at the internal combustion heat engines. Am. J. Eng. Applied Sci., 8: 127-137. DOI: 10.3844/ajeassp.2015.127.137

Petrescu, F.I.T., A. Apicella, A. Raffaella, RV. Petrescu and J.K. Calautit et al., 2016. Something about the mechanical moment of inertia. Am. J. Applied Sci., 13: 1085-1090. DOI: 10.3844/ajassp.2016.1085.1090

Petrescu, R.V., R. Aversa, B. Akash, R. Bucinell and J. Corchado et al., 2017a. Yield at thermal engines internal combustion. Am. J. Eng. Applied Sci., 10: 243-251. DOI: 10.3844/ajeassp.2017.243.251

Petrescu, R.V., R. Aversa, B. Akash, B. Ronald and J. Corchado et al., 2017b. Velocities and accelerations at the 3R mechatronic systems. Am. J. Eng. Applied Sci., 10: 252-263. DOI: 10.3844/ajeassp.2017.252.263

Petrescu, R.V., R. Aversa, B. Akash, R. Bucinell and J. Corchado et al., 2017c. Anthropomorphic solid structures n-r kinematics. Am. J. Eng. Applied Sci., 10: 279-291. DOI: 10.3844/ajeassp.2017.279.291

Petrescu, R.V., R. Aversa, B. Akash, R. Bucinell and J. Corchado et al., 2017d. Inverse kinematics at the anthropomorphic robots, by a trigonometric method. Am. J. Eng. Applied Sci., 10: 394-411.

DOI: 10.3844/ajeassp.2017.394.411

Petrescu, R.V., R. Aversa, B. Akash, R. Bucinell and J. Corchado et al., 2017e. Forces at internal combustion engines. Am. J. Eng. Applied Sci., 10: 382-393. DOI: 10.3844/ajeassp.2017.382.393

Petrescu, R.V., R. Aversa, B. Akash, R. Bucinell and J. Corchado et al., 2017f. Gears-Part I. Am. J. Eng. Applied Sci., 10: 457-472. DOI: 10.3844 /ajeassp.2017.457.472

Petrescu, R.V., R. Aversa, B. Akash, R. Bucinell and J. Corchado et al., 2017g. Gears-part II. Am. J. Eng. Applied Sci., 10: 473-483.

DOI: 10.3844/ajeassp.2017.473.483

Petrescu, R.V., R. Aversa, B. Akash, R. Bucinell and J. Corchado et al., 2017h. Cam-gears forces, velocities, powers and efficiency. Am. J. Eng. Applied Sci., 10: 491-505. DOI: 10.3844/ajeassp.2017.491.505

Petrescu, R.V., R. Aversa, B. Akash, R. Bucinell and J. Corchado et al., 2017i. Dynamics of mechanisms with cams illustrated in the classical distribution. Am. J. Eng. Applied Sci., 10: 551-567. DOI: 10.3844/ajeassp.2017.551.567

Petrescu, R.V., R. Aversa, B. Akash, R. Bucinell and J. Corchado et al., 2017j. Testing by non-destructive control. Am. J. Eng. Applied Sci., 10: 568-583. DOI: 10.3844/ajeassp.2017.568.583

Petrescu, R.V., R. Aversa, A. Apicella and F.I.T. Petrescu, 2017k. Transportation engineering. Am. J. Eng. Applied Sci., 10: 685-702.

DOI: $10.3844 /$ ajeassp.2017.685.702
Petrescu, R.V., R. Aversa, S. Kozaitis, A. Apicella and F.I.T. Petrescu, 20171. The quality of transport and environmental protection, part I. Am. J. Eng. Applied Sci., 10: 738-755. DOI: 10.3844/ajeassp.2017.738.755

Petrescu, R.V., R. Aversa, B. Akash, R. Bucinell and J. Corchado et al., $2017 \mathrm{~m}$. Modern propulsions for aerospace-a review. J. Aircraft Spacecraft Technol., 1: 1-8. DOI: 10.3844/jastsp.2017.1.8

Petrescu, R.V., R. Aversa, B. Akash, R. Bucinell and J. Corchado et al., 2017n. Modern propulsions for aerospace-part II. J. Aircraft Spacecraft Technol., 1: 9-17. DOI: 10.3844/jastsp.2017.9.17

Petrescu, R.V., R. Aversa, B. Akash, R. Bucinell and J. Corchado et al., 2017o. History of aviation-a short review. J. Aircraft Spacecraft Technol., 1: 30-49. DOI: 10.3844 jastsp.2017.30.49

Petrescu, R.V., R. Aversa, B. Akash, R. Bucinell and J. Corchado et al., 2017p. Lockheed martin-a short review. J. Aircraft Spacecraft Technol., 1: 50-68. DOI: 10.3844 jastsp.2017.50.68

Petrescu, R.V., R. Aversa, B. Akash, J. Corchado and F. Berto et al., 2017q. Our universe. J. Aircraft Spacecraft Technol., 1: 69-79. DOI: 10.3844/jastsp.2017.69.79

Petrescu, R.V., R. Aversa, B. Akash, J. Corchado and F. Berto et al., 2017r. What is a UFO? J. Aircraft Spacecraft Technol., 1: 80-90. DOI: $10.3844 /$ jastsp.2017.80.90

Petrescu, R.V., R. Aversa, B. Akash, J. Corchado and F. Berto et al., 2017s. About bell helicopter FCX-001 concept aircraft-a short review. J. Aircraft Spacecraft Technol., 1: 91-96. DOI: 10.3844/jastsp.2017.91.96

Petrescu, R.V., R. Aversa, B. Akash, J. Corchado and F. Berto et al., 2017t. Home at airbus. J. Aircraft Spacecraft Technol., 1: 97-118. DOI: $10.3844 /$ jastsp.2017.97.118

Petrescu, R.V., R. Aversa, B. Akash, J. Corchado and F. Berto et al., 2017u. Airlander. J. Aircraft Spacecraft Technol., 1: 119-148. DOI: $10.3844 /$ jastsp.2017.119.148

Petrescu, R.V., R. Aversa, B. Akash, J. Corchado and F. Berto et al., 2017v. When boeing is dreaming-a review. J. Aircraft Spacecraft Technol., 1: 149-161. DOI: 10.3844 /jastsp.2017.149.161

Petrescu, R.V., R. Aversa, B. Akash, J. Corchado and F. Berto et al., 2017w. About Northrop Grumman. J. Aircraft Spacecraft Technol., 1: 162-185. DOI: $10.3844 /$ jastsp.2017.162.185

Petrescu, R.V., R. Aversa, B. Akash, J. Corchado and F. Berto et al., 2017x. Some special aircraft. J. Aircraft Spacecraft Technol., 1: 186-203. DOI: 10.3844 /jastsp.2017.186.203

Petrescu, R.V., R. Aversa, B. Akash, J. Corchado and F. Berto et al., 2017y. About helicopters. J. Aircraft Spacecraft Technol., 1: 204-223. DOI: $10.3844 /$ jastsp.2017.204.223 
Petrescu, R.V., R. Aversa, B. Akash, F. Berto and A. Apicella et al., 2017z. The modern flight. J. Aircraft Spacecraft Technol., 1: 224-233.

DOI: 10.3844/jastsp.2017.224.233

Petrescu, R.V., R. Aversa, B. Akash, F. Berto and A. Apicella et al., 2017aa. Sustainable energy for aerospace vessels. J. Aircraft Spacecraft Technol., 1: 234-240. DOI: 10.3844/jastsp.2017.234.240

Petrescu, R.V., R. Aversa, B. Akash, F. Berto and A. Apicella et al., 2017ab. Unmanned helicopters. J. Aircraft Spacecraft Technol., 1: 241-248. DOI: 10.3844/jastsp.2017.241.248

Petrescu, R.V., R. Aversa, B. Akash, F. Berto and A. Apicella et al., 2017ac. Project HARP. J. Aircraft Spacecraft Technol., 1: 249-257. DOI: $10.3844 /$ jastsp.2017.249.257

Petrescu, R.V., R. Aversa, B. Akash, F. Berto and A. Apicella et al., 2017ad. Presentation of Romanian engineers who contributed to the development of global aeronautics-part I. J. Aircraft Spacecraft Technol., 1: 258-271. DOI: 10.3844 /jastsp.2017.258.271

Petrescu, R.V., R. Aversa, B. Akash, F. Berto and A. Apicella et al., 2017ae. A first-class ticket to the planet mars, please. J. Aircraft Spacecraft Technol., 1: 272-281. DOI: 10.3844/jastsp.2017.272.281

Petrescu, R.V., R. Aversa, A. Apicella, M.M. Mirsayar and S. Kozaitis et al., 2018a. NASA started a propeller set on board voyager 1 after 37 years of break. Am. J. Eng. Applied Sci., 11: 66-77. DOI: 10.3844 /ajeassp.2018.66.77

Petrescu, R.V., R. Aversa, A. Apicella, M.M. Mirsayar and S. Kozaitis et al., 2018b. There is life on mars? Am. J. Eng. Applied Sci., 11: 78-91. DOI: 10.3844/ajeassp.2018.78.91

Petrescu, R.V., R. Aversa, A. Apicella and F.I.T. Petrescu, 2018c. Friendly environmental transport. Am. J. Eng. Applied Sci., 11: 154-165. DOI: 10.3844/ajeassp.2018.154.165

Petrescu, R.V., R. Aversa, B. Akash, T.M. Abu-Lebdeh and A. Apicella et al., 2018d. Buses running on gas. Am. J. Eng. Applied Sci., 11: 186-201. DOI: 10.3844/ajeassp.2018.186.201

Petrescu, R.V., R. Aversa, B. Akash, T.M. Abu-Lebdeh and A. Apicella et al., 2018e. Some aspects of the structure of planar mechanisms. Am. J. Eng. Applied Sci., 11: 245-259. DOI: 10.3844/ajeassp.2018.245.259

Petrescu, RV., R. Aversa, T.M. Abu-Lebdeh, A. Apicella and F.I.T. Petrescu, 2018f. The forces of a simple carrier manipulator. Am. J. Eng. Applied Sci., 11: 260-272. DOI: 10.3844/ajeassp.2018.260.272

Petrescu, RV., R. Aversa, T.M. Abu-Lebdeh, A. Apicella and F.I.T. Petrescu, 2018g. The dynamics of the Otto engine. Am. J. Eng. Applied Sci., 11: 273-287. DOI: 10.3844/ajeassp.2018.273.287
Petrescu, RV., R. Aversa, T.M. Abu-Lebdeh, A. Apicella and F.I.T. Petrescu, 2018h. NASA satellites help us to quickly detect forest fires. Am. J. Eng. Applied Sci., 11: 288-296. DOI: 10.3844/ajeassp.2018.288.296

Petrescu, RV., R. Aversa, T.M. Abu-Lebdeh, A. Apicella and F.I.T. Petrescu, 2018i. Kinematics of a mechanism with a triad. Am. J. Eng. Applied Sci., 11: 297-308. DOI: 10.3844/ajeassp.2018.297.308

Petrescu, R.V., R. Aversa, A. Apicella and F.I.T. Petrescu, 2018j. Romanian engineering "on the wings of the wind". J. Aircraft Spacecraft Technol., 2: 1-18. DOI: 10.3844/jastsp.2018.1.18

Petrescu, R.V., R. Aversa, A. Apicella and F.I.T. Petrescu, 2018k. NASA Data used to discover eighth planet circling distant star. J. Aircraft Spacecraft Technol., 2: 19-30. DOI: 10.3844/jastsp.2018.19.30

Petrescu, R.V., R. Aversa, A. Apicella and F.I.T. Petrescu, 20181. NASA has found the most distant black hole. J. Aircraft Spacecraft Technol., 2: 31-39. DOI: 10.3844 jastsp.2018.31.39

Petrescu, R.V., R. Aversa, A. Apicella and F.I.T. Petrescu, 2018m. Nasa selects concepts for a new mission to titan, the moon of saturn. J. Aircraft Spacecraft Technol., 2: 40-52. DOI: 10.3844 jastsp.2018.40.52

Petrescu, R.V., R. Aversa, A. Apicella and F.I.T. Petrescu, 2018n. NASA sees first in 2018 the direct proof of ozone hole recovery. J. Aircraft Spacecraft Technol., 2: 53-64. DOI: 10.3844/jastsp.2018.53.64

Pisello, A.L., G. Pignatta, C. Piselli, V.L. Castaldo and F. Cotana, 2016. Investigating the dynamic thermal behavior of building envelope in summer conditions by means of in-field continuous monitoring. Am. J. Eng. Applied Sci., 9: 505-519.

DOI: 10.3844 /ajeassp.2016.505.519

Pourmahmoud, N., 2008. Rarefied gas flow modeling inside rotating circular cylinder. Am. J. Eng. Applied Sci., 1: 62-65.

DOI: 10.3844/ajeassp.2008.62.65

Pravettoni, M., C.S.P. Lòpez and R.P. Kenny, 2016. Impact of the edges of a backside diffusive reflector on the external quantum efficiency of luminescent solar concentrators: Experimental and computational approach. Am. J. Eng. Applied Sci., 9: 53-63. DOI: 10.3844 /ajeassp.2016.53.63

Qutbodin, K., 2010. Merging autopilot/flight control and navigation-flight management systems. Am. J. Eng. Applied Sci., 3: 629-630. DOI: 10.3844 /ajeassp.2010.629.630

Rajbhandari, S., Z. Ghassemlooy and M. Angelova, 2011. The performance of a dual header pulse interval modulation in the presence of artificial light interferences in an indoor optical wireless communications channel with wavelet denoising. Am. J. Eng. Applied Sci., 4: 513-519.

DOI: 10.3844/ajeassp.2011.513.519 
Rajput, R.S., S. Pandey and S. Bhadauria, 2016. Correlation of biodiversity of algal genera with special reference to the waste water effluents from industries. Am. J. Eng. Applied Sci., 9: 1127-1133. DOI: 10.3844/ajeassp.2016.1127.1133

Rajupillai, K., S. Palaniammal and K. Bommuraju, 2015. Computational intelligence and application of frame theory in communication systems. Am. J. Eng. Applied Sci., 8: 633-637. DOI: 10.3844/ajeassp.2015.633.637

Raptis, K.G., G.A. Papadopoulos, T.N. Costopoulos and A.D. Tsolakis, 2011. Experimental study of load sharing in roller-bearing contact by caustics and photoelasticity. Am. J. Eng. Applied Sci., 4: 294-300. DOI: 10.3844/ajeassp.2011.294.300

Rama, G., D. Marinkovic and M. Zehn, 2016. Efficient co-rotational 3-node shell element. Am. J. Eng. Applied Sci., 9: 420-431.

DOI: 10.3844/ajeassp.2016.420.431

Rea, P. and E. Ottaviano, 2016. Analysis and mechanical design solutions for sit-to-stand assisting devices. Am. J. Eng. Applied Sci., 9: 1134-1143. DOI: 10.3844/ajeassp.2016.1134.1143

Rhode-Barbarigos, L., V. Charpentier, S. Adriaenssens and O. Baverel, 2015. Dialectic form finding of structurally integrated adaptive structures. Am. J. Eng. Applied Sci., 8: 443-454.

DOI: 10.3844/ajeassp.2015.443.454

Riccio, A., U. Caruso, A. Raimondo and A. Sellitto, 2016a. Robustness of XFEM method for the simulation of cracks propagation in fracture mechanics problems. Am. J. Eng. Applied Sci., 9: 599-610. DOI: 10.3844/ajeassp.2016.599.610

Riccio, A., R. Cristiano and S. Saputo, 2016b. A brief introduction to the bird strike numerical simulation. Am. J. Eng. Applied Sci., 9: 946-950. DOI: 10.3844/ajeassp.2016.946.950

Rich, F. and M.A. Badar, 2016. Statistical analysis of auto dilution Vs manual dilution process in inductively coupled plasma spectrometer tests. Am. J. Eng. Applied Sci., 9: 611-624.

DOI: 10.3844/ajeassp.2016.611.624

Rohit, K. and S. Dixit, 2016. Mechanical properties of waste Biaxially Oriented Polypropylene metallized films (BOPP), LLDPE: LDPE films with sisal fibres. Am. J. Eng. Applied Sci., 9: 913-920.

DOI: 10.3844/ajeassp.2016.913.920

Rulkov, N.F., A.M. Hunt, P.N. Rulkov and A.G. Maksimov, 2016. Quantization of map-based neuronal model for embedded simulations of neurobiological networks in real-time. Am. J. Eng. Applied Sci., 9: 973-984. DOI: 10.3844/ajeassp.2016.973.984

Saikia, A. and N. Karak, 2016. Castor oil based epoxy/clay nanocomposite for advanced applications. Am. J. Eng. Applied Sci., 9: 31-40. DOI: 10.3844/ajeassp.2016.31.40
Sallami, A., N. Zanzouri and M. Ksouri, 2016. Robust diagnosis of a DC motor by bond graph approach. Am. J. Eng. Applied Sci., 9: 432-438. DOI: 10.3844/ajeassp.2016.432.438

Samantaray, K.S., S. Sahoo and C.S. Rout, 2016. Hydrothermal synthesis of CuWO4-reduced graphene oxide hybrids and supercapacitor application. Am. J. Eng. Applied Sci., 9: 584-590. DOI: 10.3844 /ajeassp.2016.584.590

Santos, F.A. and C. Bedon, 2016. Preliminary experimental and finite-element numerical assessment of the structural performance of SMAreinforced GFRP systems. Am. J. Eng. Applied Sci., 9: 692-701. DOI: 10.3844/ajeassp.2016.692.701

Sava, I., 1970. Contributions to dynamics and optimization of income mechanism synthesis. Ph.D. Thesis, I.P.B.

Semin, A.R. Ismail and R.A. Bakar, 2009a. Combustion temperature effect of diesel engine convert to compressed natural gas engine. Am. J. Eng. Applied Sci., 2: 212-216. DOI: 10.3844/ajeassp.2009.212.216

Semin, A.R. Ismail and R.A. Bakar, 2009b. Effect of diesel engine converted to sequential port injection compressed natural gas engine on the cylinder pressure Vs crank angle in variation engine speeds. Am. J. Eng. Applied Sci., 2: 154-159. DOI: 10.3844 /ajeassp.2009.154.159

Semin S., A.R. Ismail and R.A. Bakar, 2009c. Diesel engine convert to port injection $\mathrm{CNG}$ engine using gaseous injector nozzle multi holes geometries improvement: A review. Am. J. Eng. Applied Sci., 2: 268-278. DOI: 10.3844/ajeassp.2009.268.278

Semin and R.A. Bakar, 2008. A technical review of compressed natural gas as an alternative fuel for internal combustion engines. Am. J. Eng. Applied Sci., 1: 302-311. DOI: 10.3844/ajeassp.2008.302.311

Sepúlveda, J.A.M., 2016. Outlook of municipal solid waste in Bogota (Colombia). Am. J. Eng. Applied Sci., 9: 477-483. DOI: 10.3844/ajeassp.2016.477.483

Serebrennikov, A., D. Serebrennikov and Z. Hakimov, 2016. Polyethylene pipeline bending stresses at an installation. Am. J. Eng. Applied Sci., 9: 350-355. DOI: 10.3844 /ajeassp.2016.350.355

Shanmugam, K., 2016. Flow dynamic behavior of fish oil/silver nitrate solution in mini-channel, effect of alkane addition on flow pattern and interfacial tension. Am. J. Eng. Applied Sci., 9: 236-250. DOI: 10.3844 /ajeassp.2016.236.250

Shruti, 2016. Comparison in cover media under stegnography: Digital media by hide and seek approach. Am. J. Eng. Applied Sci., 9: 297-302. DOI: 10.3844/ajeassp.2016.297.302

Stavridou, N., E. Efthymiou and C.C. Baniotopoulos, 2015a. Welded connections of wind turbine towers under fatigue loading: Finite element analysis and comparative study. Am. J. Eng. Applied Sci., 8: 489-503. DOI: 10.3844/ajeassp.2015.489.503 
Stavridou, N., E. Efthymiou and C.C. Baniotopoulos, $2015 \mathrm{~b}$. Verification of anchoring in foundations of wind turbine towers. Am. J. Eng. Applied Sci., 8: 717-729. DOI: 10.3844/ajeassp.2015.717.729

Suarez, L., T.M. Abu-Lebdeh, M. Picornell and S.A. Hamoush, 2016. Investigating the role of fly ash and silica fume in the cement hydration process. Am. J. Eng. Applied Sci., 9: 134-145.

DOI: 10.3844/ajeassp.2016.134.145

Syahrullah, O.I. and N. Sinaga, 2016. Optimization and prediction of motorcycle injection system performance with feed-forward back-propagation method Artificial Neural Network (ANN). Am. J. Eng. Applied Sci., 9: 222-235.

DOI: 10.3844/ajeassp.2016.222.235

Sylvester, O., I. Bibobra and O.N. Ogbon, 2015a. Well test and PTA for reservoir characterization of key properties. Am. J. Eng. Applied Sci., 8: 638-647. DOI: 10.3844/ajeassp.2015.638.647

Sylvester, O., I. Bibobra and O. Augustina, 2015b. Report on the evaluation of Ugua J2 and J3 reservoir performance. Am. J. Eng. Applied Sci., 8: 678-688. DOI: 10.3844/ajeassp.2015.678.688

Taher, S.A., R. Hematti and M. Nemati, 2008. Comparison of different control strategies in GAbased optimized UPFC controller in electric power systems. Am. J. Eng. Applied Sci., 1: 45-52.

DOI: 10.3844/ajeassp.2008.45.52

Takeuchi, T., Y. Kinouchi, R. Matsui and T. Ogawa, 2015. Optimal arrangement of energy-dissipating members for seismic retrofitting of truss structures. Am. J. Eng. Applied Sci., 8: 455-464. DOI: 10.3844/ajeassp.2015.455.464

Taraza, D., N.A. Henein and W. Bryzik, 2001. The frequency analysis of the crankshaft's speed variation: A reliable tool for diesel engine diagnosis. J. Eng. Gas Turbines Power, 123: 428-432. DOI: $10.1115 / 1.1359479$

Tesar, D. and G.K. Matthew, 1974. The Design of Modeled Cam Systems. In: Cams and Cam Mechanisms, Rees Jones, J. (Ed.), MEP, London and Birmingham, Alabama.

Theansuwan, W. and K. Triratanasirichai, 2011. The biodiesel production from roast Thai sausage oil by transesterification reaction. Am. J. Eng. Applied Sci., 4: 130-132.

DOI: $10.3844 /$ ajeassp.2011.130.132

Thongwan, T., A. Kangrang and S. Homwuttiwong, 2011. An estimation of rainfall using fuzzy setgenetic algorithms model. Am. J. Eng. Applied Sci., 4: 77-81. DOI: 10.3844/ajeassp.2011.77.81

Tourab, W., A. Babouri and M. Nemamcha, 2011. Experimental study of electromagnetic environment in the vicinity of high voltage lines. Am. J. Eng. Applied Sci., 4: 209-213.

DOI: 10.3844 /ajeassp.2011.209.213
Tsolakis, A.D. and K.G. Raptis, 2011. Comparison of maximum gear-tooth operating bending stresses derived from niemann's analytical procedure and the finite element method. Am. J. Eng. Applied Sci., 4: 350-354. DOI: 10.3844/ajeassp.2011.350.354

Vernardos, S.M. and C.J. Gantes, 2015. Cross-section optimization of sandwich-type cylindrical wind turbine towers. Am. J. Eng. Applied Sci., 8: 471-480. DOI: 10.3844/ajeassp.2015.471.480

Wang, L., T. Liu, Y. Zhang and X. Yuan, 2016. A methodology for continuous evaluation of cloud resiliency. Am. J. Eng. Applied Sci., 9: 264-273. DOI: 10.3844/ajeassp.2016.264.273

Wang, L., G. Wang and C.A. Alexander, 2015. Confluences among big data, finite element analysis and high-performance computing. Am. J. Eng. Applied Sci., 8: 767-774. DOI: 10.3844/ajeassp.2015.767.774

Wang, J. and Y. Yagi, 2016. Fragment-based visual tracking with multiple representations. Am. J. Eng. Applied Sci., 9: 187-194. DOI: 10.3844/ajeassp.2016.187.194

Waters, C., S. Ajinola and M. Salih, 2016. Dissolution sintering technique to create porous copper with sodium chloride using polyvinyl alcohol solution through powder metallurgy. Am. J. Eng. Applied Sci. 9: 155-165. DOI: 10.3844/ajeassp.2016.155.165

Wessels, L. and H. Raad, 2016. Recent advances in point of care diagnostic tools: A review. Am. J. Eng. Applied Sci., 9: 1088-1095.

DOI: 10.3844/ajeassp.2016.1088.1095

Wiederrich, J.L. and B. Roth, 1974. Design of Low Vibration Cam Profiles. In: Cams and Cam Mechanisms, Rees Jones, J. (Ed.), MEP, London and Birmingham, Alabama.

Yang, M.F. and Y. Lin, 2015. Process is unreliable and quantity discounts supply chain integration inventory model. Am. J. Eng. Applied Sci., 8: 602-610.

DOI: 10.3844 ajeassp.2015.602.610

Yeargin, R., R. Ramey and C. Waters, 2016. Porosity analysis in porous brass using dual approaches. Am. J. Eng. Applied Sci., 9: 91-97. DOI: 10.3844/ajeassp.2016.91.97

You, M., X. Huang, M. Lin, Q. Tong and X. Li et al., 2016. Preparation of $\mathrm{LiCoMnO}_{4}$ assisted by hydrothermal approach and its electrochemical performance. Am. J. Eng. Applied Sci., 9: 396-405. DOI: 10.3844/ajeassp.2016.396.405

Zeferino, R.S., J.A.R. Ramón, E. de Anda Reyes, R.S. González and U. Pal, 2016. Large scale synthesis of $\mathrm{ZnO}$ nanostructures of different morphologies through solvent-free mechanochemical synthesis and their application in photocatalytic dye degradation. Am. J. Eng. Applied Sci., 9: 41-52. DOI: 10.3844 /ajeassp.2016.41.52 
Zhao, B., 2013. Identification of multi-cracks in the gate rotor shaft based on the wavelet finite element method. Am. J. Eng. Applied Sci., 6: 309-319.

DOI: 10.3844/ajeassp.2013.309.319

Zheng, H. and S. Li, 2016. Fast and robust maximum power point tracking for solar photovoltaic systems. Am. J. Eng. Applied Sci., 9: 755-769.

DOI: 10.3844 /ajeassp.2016.755.769

Zotos, I.S. and T.N. Costopoulos, 2009. On the use of rolling element bearings' models in Precision maintenance. Am. J. Eng. Applied Sci., 2: 344-352. DOI: 10.3844/ajeassp.2009.344.352

Zulkifli, R., K. Sopian, S. Abdullah and M.S. Takriff, 2008. Effect of pulsating circular hot air jet frequencies on local and average nusselt number. Am. J. Eng. Applied Sci., 1: 57-61. DOI: 10.3844/ajeassp.2008.57.61

Zulkifli, R., K. Sopian, S. Abdullah and M.S. Takriff, 2009. Experimental study of flow structures of circular pulsating air jet. Am. J. Eng. Applied Sci., 2: 171-175. DOI: 10.3844/ajeassp.2009.171.175

Zurfi, A. and J. Zhang, 2016a. Model identification and wall-plug efficiency measurement of white LED modules. Am. J. Eng. Applied Sci., 9: 412-419. DOI: 10.3844/ajeassp.2016.412.419

Zurfi, A. and J. Zhang, 2016b. Exploitation of battery energy storage in load frequency control-a literature survey. Am. J. Eng. Applied Sci., 9: 1173-1188. DOI: $10.3844 /$ ajeassp.2016.1173.1188

\section{Source of Figures:}

Petrescu, 2008

\section{Nomenclature}$$
J^{*}
$$$$
J_{M a x}^{*}
$$$$
J_{\text {min }}^{*}
$$$$
J_{m}^{*}
$$$$
J^{*}
$$$$
\eta_{i}
$$$$
\eta
$$$$
\tau
$$$$
\delta
$$
is the minimum moment of inertia (mass is the moment of inertia (mass or mechanical) reduced to the camshaft

is the maximum moment of inertia (mass or mechanical) reduced to the camshaft or mechanical) reduced to the camshaft is the average moment of inertia (mass or mechanical, reduced to the camshaft) is the first derivative of the moment of inertia (mass or mechanical, reduced to the camshaft) in relation with the $\varphi$ angle is the momentary efficiency of the campusher mechanism

is the mechanical yield of the camfollower mechanism

is the transmission angle

is the pressure angle

is the movement of the pusher $h$

$s^{\prime}$

$s^{\prime \prime}$

$s^{\prime \prime \prime}$

$x$

$x^{\prime}$

$x^{\prime \prime}$

$\ddot{x}$

$\ddot{\mathrm{x}}$

$v_{\tau} \equiv \dot{\mathrm{s}}$

$a_{\tau} \equiv \dot{\mathrm{s}}$

$\varphi$

$K$

$k$

$x_{0}$

$m_{c}$

$m_{T}$

$\omega_{m}$

\section{$n_{c}$}

$n=n_{m}$

$\omega$

$\varepsilon$

$r_{0}$

$\rho=r$

is the follower stroke $h=s_{\max }$

is the first derivative in function of $\varphi$ of the tappet movement, $\mathrm{s}$

is the second derivative in raport of $\varphi$ angle of the tappet movement, $\mathrm{s}$

is the third derivative of the tappet movement $s$, in raport of the $\varphi$ angle is the real, dynamic, movement of the pusher

is the real, dynamic, reduced tappet speed

is the real, dynamic, reduced tappet acceleration

is the real, dynamic, acceleration of the tappet (valve).

is the normal (cinematic) velocity of the tappet

is the normal (cinematic) acceleration of the tappet

is the rotation angle of the cam (the position angle)

is the elastic constant of the system

is the elastic constant of the valve spring

is the valve spring preload (pretension)

is the mass of the cam

is the mass of the tappet

the nominal angular rotation speed of the cam (camshaft)

is the camshaft speed

is the motor shaft speed $n_{m}=2 n_{c}$

is the dynamic angular rotation speed of the cam

is the dynamic angular rotation cceleration of the cam

is the radius of the base circle

is the radius of the cam (the position vector radius)

$\theta \quad$ is the position vector angle

$x=x_{c}$ and $y=y_{c}$ are the Cartesian coordinates of the cam

$D \quad$ is the dynamic coefficient

$\dot{D} \quad$ is the derivative of $D$ in function of the time

$D^{\prime} \quad$ is the derivative of $D$ in function of the position angle of the camshaft, $\varphi$

$F_{m} \quad$ is the motor force

$F_{r} \quad$ is the resistant force. 